\title{
THE PAST AND THE FUTURE OF TIME IN THE PRESENT IN 1 JOHN
}

\author{
Dirk G. Van der Merwe \\ (University of South Africa)
}

\begin{abstract}
The reflection on and definition of time in this research have been directed at trying to understand how the author of 1 John used his time references to make sense of his experiences in the Johannine community.

The objective in this article is to point out how the author distinguishes between the past, the present and the future and also how closely he has interwoven and blended his perceptions to objectify time. In order to achieve this, the author's point of departure is that Jesus Christ was made the hermeneutical tool that enables us to understand the past, the present and the future of time. Methodologically this paper starts with a comparison between time in antiquity and time in the New Testament, which enables the author to construct a basic framework for the discussion of "time" in the rest of this paper. In the latter part of the paper the investigation of "the past and the future of time in the present in 1 John" is conducted from a sociocultural and a sociotheological perspective on time. A time diagram has been constructed and added in an addendum in order to help to determine the basic content of the investigation.
\end{abstract}

\section{Introduction}

The relation of Christians to the world and their actions in the world are defined by their specific location in time. The manner in which they live

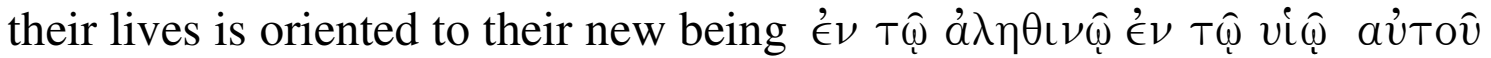
'I lived (2:6) illustrates how the events of the eschatological future already shine into the present as a source of strength, how the reality of the future already determines the present (cf. Bultmann 1983:79ff). In the investigation of eschatological time references here, 1 John has been selected because of my interest in this epistle's interesting eschatological teaching. The investigation to be conducted here is not a linguistic approach, but rather a literary approach of eschatological time references and the interweaving of these throughout the epistle.

Statements made by Bourdieu, Malina and - very recently - Hawking about time, can take us a long way towards understanding the eschatologial time perception of the author of 1 John (hereafter Elder) ${ }^{1}$, and consequently 
help us to understand the content of this epistle. Bourdieu (1963:55-6) made the statement that "Awareness of time is not simply one of the dimensions of [one's] life experience, but rather the form in terms of which that experience is organized." Writing from a different perspective, Malina (1998:180) states that people always have an image of time and space in the mental maps which they use to make sense of their experiences. ${ }^{2}$ The assessment of placement and process sets the coordinates of that cognitive map upon which we situate ourselves and the persons, objects and religious experiences we need to understand. In a recent visit to South Africa (12 May 2008) by the mathematician Stephen Hawking (Elsabé Brits: Beeld 13/05/2008), he stated in his lecture in Cape Town that the problem with the beginning of time is the same problem we have with the end of time - in the same manner as when people at a time have thought that the earth is flat. He also said that when the general relativity theory of Einstein is combined with quantum physics, time reacts differently. Time is then measured in degrees of wideness and the question about time gets a different perspective.

What the above statements imply is that the perspective of time can be changed so that reflection on and the definition of time can be used to make sense of one's experiences. This can then create a form in terms of which experience can be organised. Influenced by the above statements about time, the objective of this paper will be to explore the way the Elder managed to use eschatological time indications, which he objectifies in Jesus Christ, to organise his experience of the Christian way of living to make sense in his time. It will be pointed out how the Elder reevaluated the past and redefined the future in relation to the present to make sense of his circumstances and time frame so as to re-experience the past and to experience the future proleptically in the present. His sense of time within an eschatological garb makes this easier for him.

Methodologically this paper will start with a comparison between time in antiquity and time in the New Testament in order to construct a basic framework for the discussion of "time" in the rest of this paper. In the latter part of the paper the investigation of "the past and the future of time in the present in 1 John" will be conducted from the perspective of a sociocultural and a sociotheological understanding of time. 


\section{The understanding of time in antiquity}

\subsection{Introduction}

In order to understand what the Elder was trying to achieve in 1 John regarding his eschatological thinking, we need to consider how time was understood in antiquity and how the New Testament perspective on time agreed with and differed from this understanding of time in antiquity. In this section we merely take a brief general look at the major perspectives on time. In the following section we will concentrate more specifically on time-perspectives in 1 John.

\subsection{A cyclic-linear understanding of time}

\subsubsection{The significance of time from a cyclical ${ }^{3}$ perspective}

There is evidence of a holistic cyclical time perspective in ancient Greece (cf. Von Rad 1965:102; Dunn 1998:462). ${ }^{4}$ Puech (1957:40f) gives a fine exposition of a cyclical conception of this kind:

Dominated by an ideal of intelligibility which finds authentic and full being only in that which is in itself and remains identical with itself, in the eternal and immutable, the Greeks regard movement and change as inferior degrees of reality, at which, at best, identity can be apprehended in the form of permanence and perpetuity, hence of recurrence. The circular movement which assures the survival of the same things by repeating them, by bringing about their continuous return is the perfect and most immediate expression (hence that which is closest to the divine) of the immobility at the summit of the hierarchy. According to the famous Platonic definition, the time which is determined and measured by the revolution of the celestial spheres is the mobile image of immobile eternity which it imitates by moving in a circle. ${ }^{5}$ Consequently both the entire cosmic process and the time of our world of generation and decay develop in a circle or according to an indefinite succession of cycles, in the course of which the same reality is made, unmade, and remade, in conformity with an immutable law ...

There was wide acceptance among Greek philosophers of the conception of the "Great Year", which was probably Babylonian in origin. This cyclical conception was described in the third century B.C.E. when Berossus popularised the Chaldean doctrine of the "Great Year" in a form that spread 
through the entire Hellenistic world (whence it later passed to the Romans). The "Great Year" consists of 36,000 solar years (the corresponding number of millennia varies from school to school), and every Great Year event in the entire cosmos or on earth repeats itself down to the minutest detail. Needham (1981:133) advances the theory that this is due to "resumption by the planets and constellations by their original places". According to this doctrine of the "Great Year", the universe is eternal but it is periodically destroyed and reconstituted every Great Year. When the seven planets assemble in Cancer ("Great Winter") there will be a deluge; when they meet in Capricorn (i.e., at the summer solstice of the Great Year) the entire universe will be consumed by fire. It is probable that this doctrine of periodic universal conflagrations was also held by Heraclitus ${ }^{6}$ (e.g. Fragment $26 \mathrm{~B}=66 \mathrm{D})$. It also dominates the thinking of Zeno and the entire Stoic cosmology (Eliade 2005:87f). ${ }^{7}$

The same might be said about the Israelite tradition. A cyclical time perspective is present here as well. In the cult we also find sacred time, which has a cyclical character. ${ }^{8}$ Life is periodically renewed in the cult (a cultic-cyclical repetition), as is time itself, through the repetition of the acts of creation. "Every new year is a repetition of the time of the beginning, that is, a repetition of the cosmogony."

Just as the miracles of Israel's time of formation were re-actualized in the cult, so, too, was the making of the covenant on Sinai (Ps 68:17). The covenant was re-experienced in the festival procession. The concept of the renewal of the covenant was to assure the people that the coming year would be a year of blessing, characterised by fertility, peace and security from evil powers and hostile peoples (Steensgaard 1993:68). However, the circularity present in this understanding of time also had room for a conscious distinction between past, present and future (69). The same understanding of time recurs in the Passover celebration. The Passover festival (and feast of unleavened bread) was linked with the tradition of the Exodus. Its dramatic formulation in Ex 12:11 indicates that the Passover events were re-experienced; they were primeval events which repeated themselves in the festival. This cultic-cyclical understanding of time disappeared later. ${ }^{9}$ Hence, whereas in the Hellenic world cyclical time was a matter of cosmogony, in the Jewish world it was a matter of culticcyclical repetition.

Even in Christianity, a cyclical time line occurs when the timeline heads towards the future marked by the reappearance of the Messiah (parousia: 1 
John $2: 28 ; 3: 2 ; 4: 17)$, or any other entity which exists at the beginning of the timeline ( $1: 2$ ). This is certainly not an irreversible timeline, but a return to the beginning or transference of the beginning to the end; the result is a completed cycle as the timeline attaches to the beginning. The final stage is marked by the restoration of the return of the preexistent Messiah at the beginning (Malina 1998:199ff). This cyclical timeline was centred on the return of a person and the return of a condition.

\subsubsection{The significance of time from a linear perspective}

The triad perspective on time seems to have been the most common and important classification of time in antiquity. Plato, for instance, classified time as "past, present and future" (Tim 37e-38b). He contrasted the eternity of the creator of the world with beings which have a past, present and future, thereby using the triad to clarify the difference between what is eternal and what is contingent (Tim. 38a).

Concerning the classification of time, Malina noted that not only do different cultures mean different things by "past," "present," and "future", they also value these concepts differently in their lives. One of these time indications seems to be dominant in certain cultures, and in fact we can say that there are "future oriented" people, "present oriented" people and "past oriented" people. No culture ever seems to have been exclusively one of these, but to have had a dominant preference for one orientation with a secondary but minor one for another (see Malina 1998).

Past orientation harks back to and relies on a written canon for inspiration and guidance: Homer for the Greeks and the Scriptures for the Israelites. Past-oriented people value certain objects like mountains, springs or temples for in the past they became sacred in their mythology and maintain their preeminence. Further, past events (famines, earthquakes, the exodus, entrance into Canaan, etc) serve as time markers. Genealogies likewise indicate the importance of the past, for belonging to an ancient line served as the primary qualification for certain roles and status positions, such as the priesthood in Israel. Prominent figures from the past, such as Homer, Plato, Moses and David, also serve as time markers.

The meaning of present time in peasant communities is reflected in Pierre Bourdieu's study (1963; also Malina 1996). Because "present" is understood to cover so much, the understandings of "past" and "future" are 
pushed aside and made to apply to more distant and even imaginary times. Malina states that cultures with a present-forthcoming orientation a) set their goals in the present, b) initiate actions to achieve these goals, c) thus see the forthcoming as continuous with the present.

Future: By future time is meant the abstract sphere which lies beyond the horizon of the experienced world. It refers to all the possible events that do not actually exist. The future cannot be known, because it is the exclusive domain of God and those to whom it has been revealed by God. It may be utterly discontinuous with the experienced world, since "with God all things are possible". Hence, unlike present-oriented cultures, futureoriented cultures assume the following: a) goals are set for the distant future; b) present activity occurs to achieve remote goals; but c) there is temporal integration between the distant future and the present.

Ancient Mediterranean man was very aware of the future. What is to happen in the future has already been written into the present and the past for Christians, especially in the life of Jesus. It was a future clarified by the events of the present and the past.

According to Cullmann (1962:81; see also Dunn 1998:464), the biblical timeline divides into three sections: time before the creation; time from the creation to the parousia; and time after the parousia. Further, Judaism is interwoven into this threefold division, which is never discarded, namely the twofold division of this age and the coming one. In this Jewish twofold division everything is viewed from the perspectives of the past and the future. ${ }^{10}$ The decisive mid-point ${ }^{11}$ of the two-part timeline appears here as the expected coming of the Messiah, the coming of the Messianic time of salvation. In Judaism, this is the point at which the great dividing point lies that separates the entire course of events into the halves. This implies that for Judaism the midpoint of the line which signifies salvation still lies in the future.

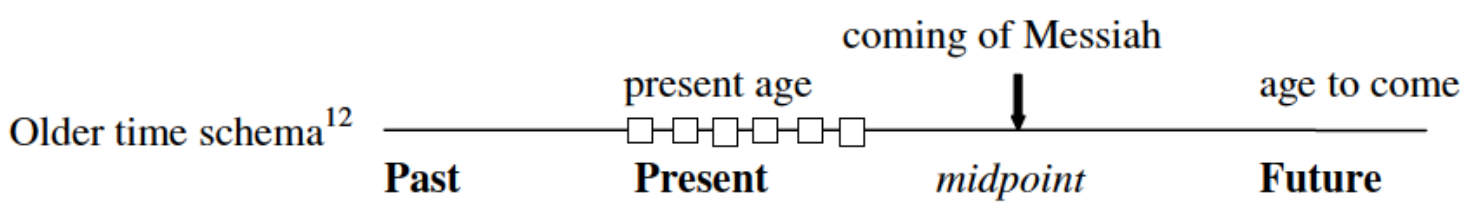

For the early Christians, the culminating act after the death of Jesus is the fact of the resurrection of Christ. No other point of time in the entire process, either in the past or in the future, can have so central a significance as this one does for the early Christians who are convinced that Jesus Christ 
has risen from death. The positive conviction that this Christ event has given a new centre to time is rooted in the faith that the fulfilment has already taken place. It is no longer the parousia, but rather the cross and resurrection of Christ that constitute the central point and meaning of all that occurs (Cullmann 1967:86; see also Delling (1965:102f; 106).

The chronologically new thing which Christ brought is the concept that for Christianity the midpoint, since Easter, no longer lies in the future. This assertion is shared by the entire early Christian church, namely that the midpoint of the process has already been reached.

The midpoint of time is no longer the future coming of the Messiah, but rather the historical life and work of Jesus Christ, already concluded in the past.

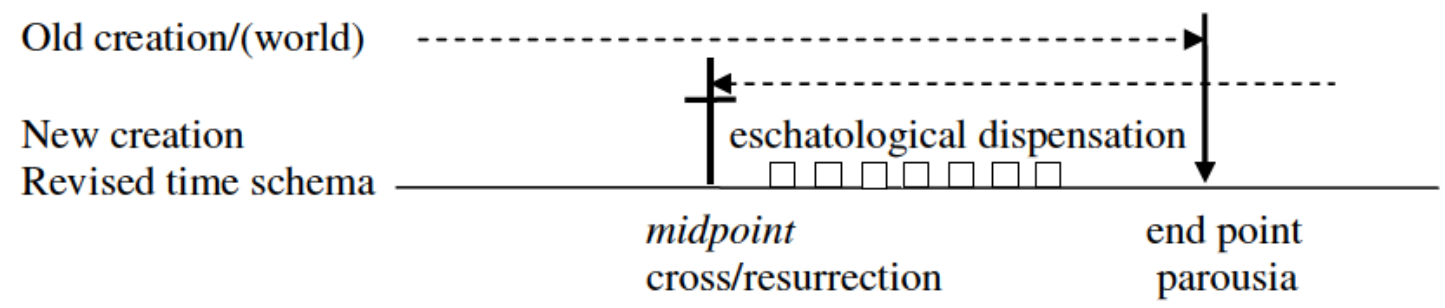

$\begin{array}{lll}\text { Past } & \text { Present } & \text { Future }\end{array}$

From the NT it seems clear that the core of the eschatological events is Jesus Christ. Most of the eschatological events revolve around Jesus (see e.g. 1 John). In his mission (incarnation, ministry, crucifixion and resurrection) OT and NT eschatology are linked. In him the OT promises are fulfilled (see the gospel of Matthew, Hebrews), but he is also the inauguration of the NT eschatological events.

\subsection{Conclusion}

In this section it became evident that time in early Christian circles was closely related to time in antiquity (Greek and Judaic ${ }^{13}$ worlds). They both have conceptualised cyclical and linear time perspectives. These two time perspectives (cyclical and linear) can be distinguished but not be separated. They complement one another. The one is to be understood with regard to the other. Linear time is necessary to complete the cycle and the cyclical time event takes place through the linear time event. The linear time indication is an inclusio of the cyclical time-period which starts beyond 
time and returns to it. The fundamental question is not linear versus cyclical, but whether the cycle occurs only once or continues indefinitely ${ }^{14}$.

Early Christianity differs in its linear time perspective from the GrecoJudaic worlds in the sense that for the early Christians Christ existed before time (was with the Father - John 1:1-5; 1 Jn 1:2). He was the midpoint of time (incarnation, crucifixion and resurrection - $1 \mathrm{Jn} 1: 2 ; 3: 16 ; 4: 9,10,14$ ), he was the end focus of time (parousia - 1 Jn 2:28; 3:2; 4:16-18). Because for them so many things revolve around Christ, time became the form in terms of which Christian experiences are organised (cf. Bourdieu 1963:55$6)$.

The major difference between the Early Christian and Greco-Judaic worlds regarding the cyclical time perspective was that in the case of the Greeks the cyclical repetition was all about the eternal universe that is periodically destroyed and reconstituted (Greeks). In Judaism this cyclical experience was defined in terms of soteriology. In the case of Early Christianity no cyclical repetition occurs. There is only one cycle which is concerned with a person and the cosmological position of that person, but with soteriological consequences for others.

The above discussion of cyclic-linear time creates a time perspective in which the dimension of time for the Elder has to be understood in the sense that he has utilised the time perspective to organise and regulate the circumstances of the Johannine community. In the following section it will be pointed out how the Elder applied the image of time and space contained in his mental map. His assessment of placement and process sets the coordinates of his cognitive map upon which he situated himself, the community and the religious experiences they needed to understand (cf. Malina 1998:180).

\section{The past and the future of time in the present in $1 \mathrm{John}$ \\ 3.1 Introduction}

In the previous section we tried to construct a time structure and to point out how Christianity relates to, but also differs from the time structures in antiquity. In this section we will investigate the cognitive map of time upon which the Elder situated himself, the community and the religious experiences they need to understand. This will be conducted from the perspective of (1) a sociocultural understanding of time in the first century 
Mediterranean context and (2) a sociotheological understanding of time in 1 John.

\subsection{A sociocultural understanding of time in $1 \mathrm{John}$ within the context of first-century Mediterranean time perceptions ${ }^{15}$}

The Mediterranean people of the first century had strong ties with the present. For them the present was regarded as the first-order temporal preference (e.g. Matt 6:34; POxy. 655:1; Q Matt 6:11; Luke 11:3), with the past and future as secondary. This was due to a social system that focused on things that had a concrete existence. What belongs to experienced time is the present (Malina 1996:188). But when these people experienced problems in the present that they found it difficult to deal with they sought answers in the past. The past directly influenced the present. The light from the past clarified the present. The past was the testing ground for the present. ${ }^{16}$ Human nature, after all, remained the same and God extends across time. This meant that they constantly had to measure their identity, all that had happened to them, and their conduct (right and wrong) by what had happened in the past. That determined their present and bore them into the future. The idea that God has always been there, is still there, and will be in the future, is the warranty for the bond between present and past. The effects of hope do lie in the future, but its roots and certainty are in the past (cf. Malina 1996:192).

More specifically, the time outside the horizon of the "experienced" world can be referred to as "imaginary time" because the past and the future were abstract and imaginary (Malina 1996:192). Imaginary time covers everything in the past and future that does not exist in the present. What may appear absurd and impossible in the context of experience may be realised in remote times and places. For the followers of Jesus referred to in 1 John the existence of Jesus with the Father and the parousia of Jesus belonged to the imaginary time zone.

The forthcoming was the unfolding or developing horizon of the experienced present. There was no reference to what was going to be and must be because it already is (to be like Jesus). And the discerning know that it already is because it can be clearly seen as deriving from what is. What is forthcoming is perceived in the same way as that which is actually present and to which the forthcoming is linked by an organic unity. Potential events are already present in some actual reality. They do not arise from some statistically infinite number of possibilities that have an 
equal chance of coming about or not occurring. Rather, potential events come about, since they are just as much present as any events that are actually present. What is forthcoming stands at the concrete horizon of the present. It need not merely be imagined, since it can be directly perceived. What is distinctive about the forthcoming in comparison with the future is the degree of immediate and direct organic connection with some presently experienced person, event or process.

In the Johannine community the Elder and his adherents had a lot of difficulty with a group of deceivers who, according to him, destroyed the koinonia in the community. How then do you fill the present with a sensible content? In order to cope with this situation and to give meaning to life "now," he uses this above discussed sociocultural time concept with regard to the past and the future and adapts it to fit his doctrine. ${ }^{17}$

The result of such a focus is that what the Elder is aware of about the past relative to what he is aware of at present as well as what he is aware of regarding the future form a single meaningful now, the actual present. Thus for the Elder as well the three time sectors (past, present and future) exist and overlap. Past eschatology ${ }^{18}$ shifts forward and future eschatology shifts backward into the present to overlap with the present. The antecedent and forthcoming blend in with the continuing. The present, then, is a single context of meaning that includes the incarnation, crucifixion, intercession and parousia of Jesus Christ. For the Elder the future bound up with the present as well as the activity of fellowship he referred to in chapter 1 that is still resonating in the present are all part of the actual present. These forward and backward shifts were made possible when time was objectified in Jesus Christ and when Christ became time. It seems as if the Elder thinks about eschatological time in terms of a person. Eschatological salvation is connected with a person and lies with and in the person, Jesus Christ; it has already started with Christ's incarnation and reaches towards the parousia.

The questions that arise are, "How can time be objectified? How does eschatological time endure with a person?" It may be when the time dimension is organised in another form. Eschatological time is objectified in Christ when he becomes the centripetal and certifugal points of eschatological time - the past, present and future revolve around him and converge in him, according to the Elder. Actually, he becomes the centre around which all the past, the present and the future eschatological events revolve. The reason may be that he exists beyond time. For the Elder God became present through Christ. Then eschatological time moved out of a 
time perspective into a person-perspective. This makes the present significant for the Elder because it is filled with an eschatological figure, Jesus Christ, with God's presence and heavenly qualities apparent in Christ. Hence, time is not empty, but full of meaning through "the real and therefore the comforting and commanding presence of God" (Berkhouwer 1975:32) through Christ.

This discussion of sociocultural time showed that the Elder used the extended present time frame of his time and linked it to Christ in order to objectify time ${ }^{19}$. The next investigation on the socio-theological understanding of time in 1 John is intended to verify and to show how the Elder objectified time.

\subsection{A socio-theological understanding of time in $1 \mathrm{John}$}

In this subsection we will identify the time indications in 1 John (3.3.1) which will enable us to identify the Son of God as the hermeneutical key for the construal of time in 1 John (3.3.2). This will open the door to an investigation of the eschatological scenario in 1 John - the objectification of time (3.3.3). This will cast light on the title, "The past and the future of time in the present in 1 John".

\subsubsection{Time indications in $1 \mathrm{John}$}

A distinction can be drawn between formal and informal time indicators. Formal time indications are reflected by the different time modes of the verbs while informal indications are evident in time phrases, time adverbs and time adjectives. In this paper the emphasis will fall on the few informal indications which are contextually distinguished. From the analysis the following time frames can be distinguished: eternal past, indefinite past, present, indefinite present, pending future, future and eternal future. See also addendum $\mathrm{A}$.

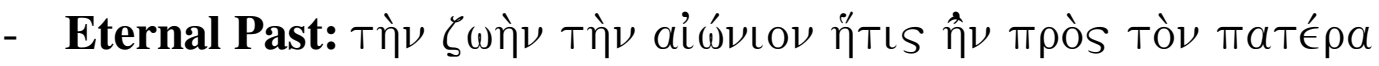
$(1: 2)$.

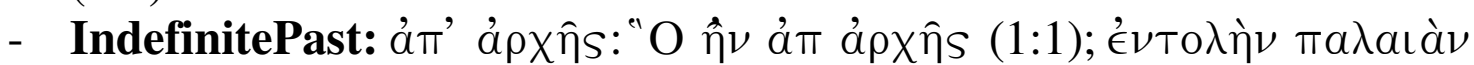

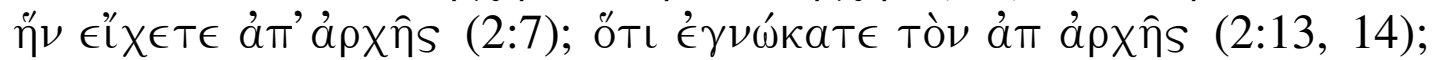

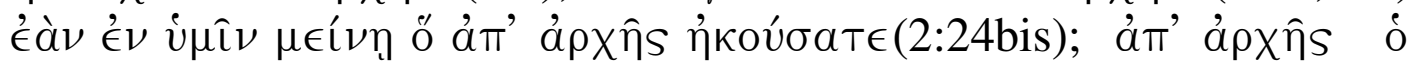

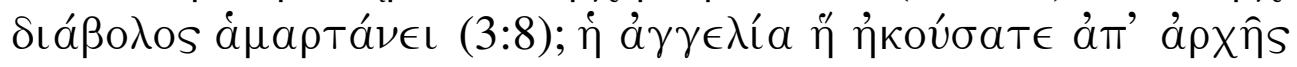
(3:11). 


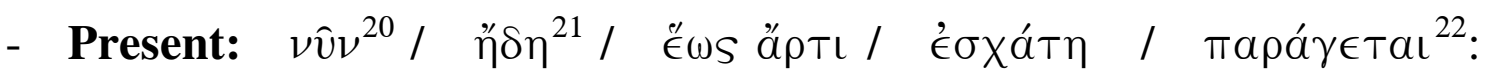

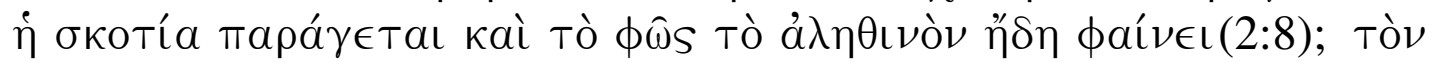

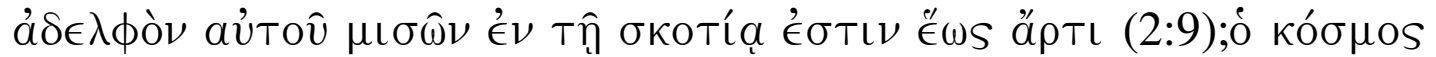

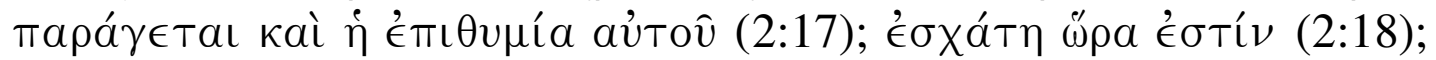

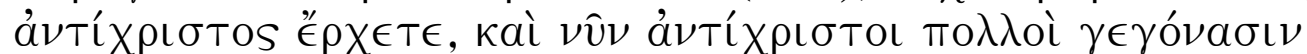

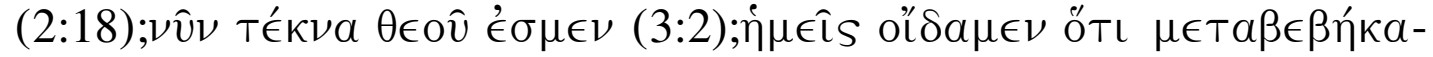

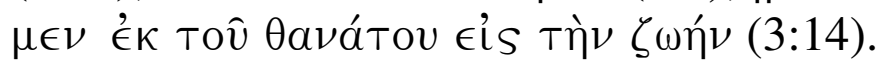

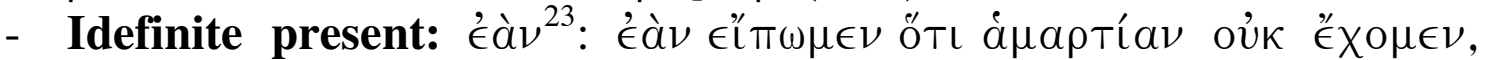

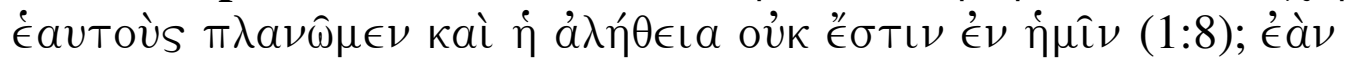

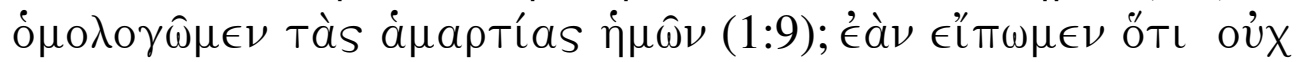
$\dot{\eta} \mu \alpha \rho т \eta ́ \kappa \alpha \mu \in \nu \quad(1: 10)$.

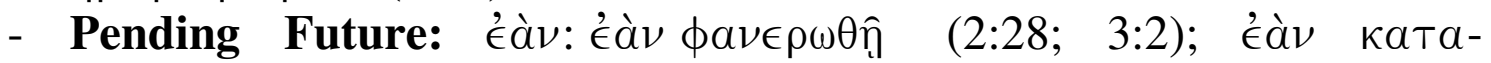

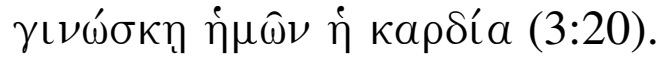

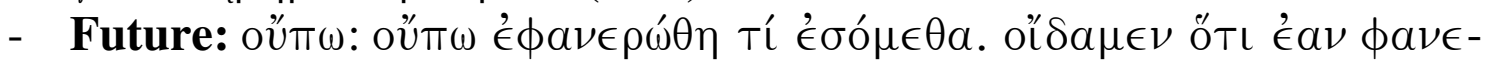

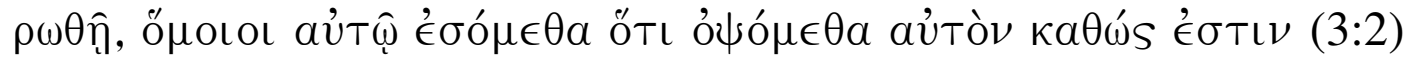

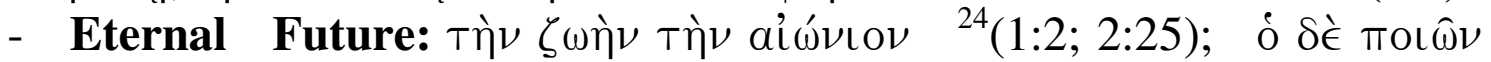

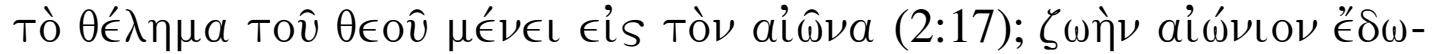

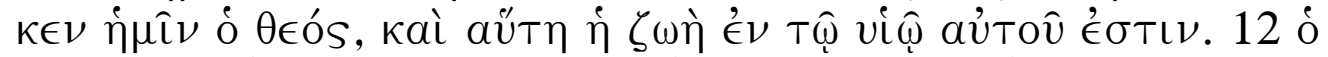

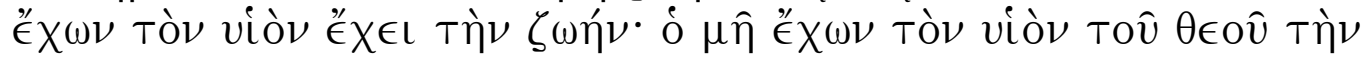

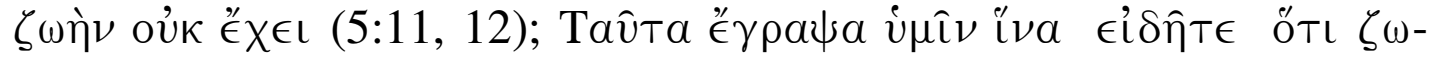

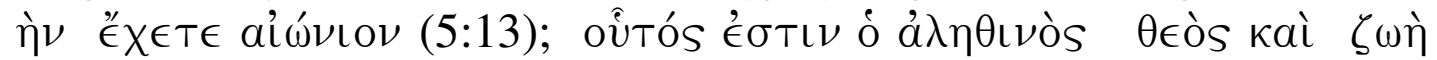
aíúvios (5:20).

This analysis clearly relates to the above discussion (section 2) of time in antiquity. It is clear from this analysis that linear as well as cyclic ${ }^{25}$ perspectives of time occur. These time references, which have been presented diagrammatically in addendum A, relate mostly to the Elder's eschatological understanding and interpretation of the circumstances and events in the Johannine community. The "eternal past" (1:2) refers to the Son as being with the Father before creation, that is to his existence before time. This is linked to the references to "eternal future", where these references refer not only to a "new quality of life" but also to existence beyond time (share in divine life). The other references to time refer to the triadic perspective of time (past - present - future).

Most of these closely interwoven time references revolve around the person of Jesus Christ the Son of God. Thus the Son forms the centrifugal/centripetal point of these references to constitute the hermeneutical key for the construal of time in 1 John. 


\subsubsection{The Son the hermeneutical key for the construal of time in 1 John}

For the Son to be the hermeneutical key for the construal of time in 1 John he has to be the focal point in each time sector (past, present, future). He can only be this if he exists beyond time. In this subsection it will be pointed out how the Elder characterises the existence of the Son as not existentially part of creation. He exists, according to the Elder, beyond time but was revealed in time for some time to reappear at the end of time. This legitimises the Son as being present in different modes of existence in the community in the past, present and future, while also being continuously present with the Father ${ }^{26}$. This can be verified from 1:1-2 and 5:20 where

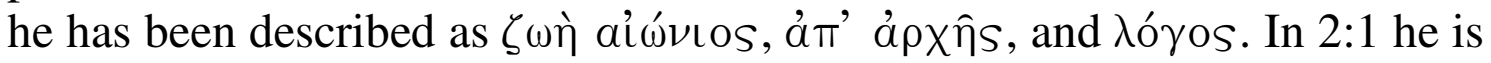
referred to as an advocate which believers have with the Father when they

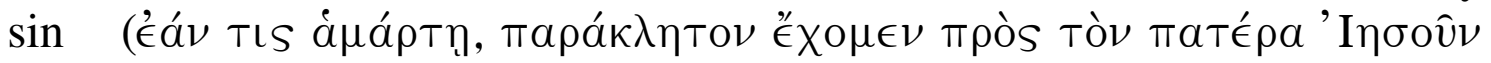

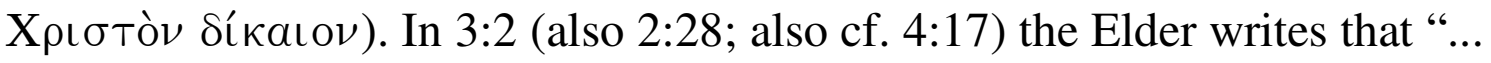
when he is revealed, we will be like him, for we will see him as he is"

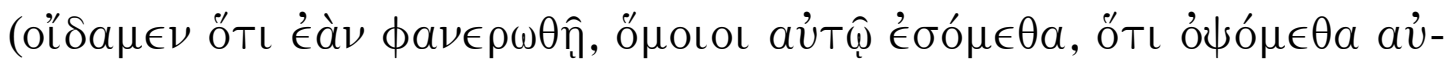

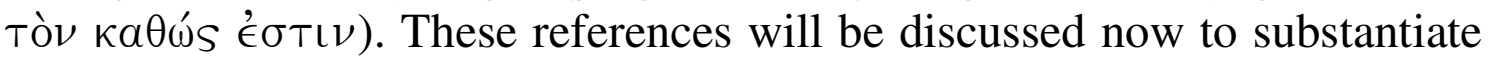
this statement about the existence of the Son of God beyond time for the Elder.

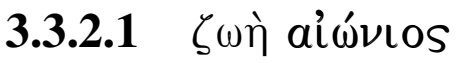

There are four references in 1 John which refer to the Son as "life" $(1: 1,2)$ or "eternal life" $(1: 2 ; 5: 20)$. The Elder starts and ends 1 John with this reference. This seems to indicate that the whole epistle is an inclusio about "eternal life". In 1:2 the Elder writes "... this life was revealed, and we have seen it and testify to it, and declare to you the eternal life that was with the Father and was revealed to us..." In 5:20 he writes "He is the true God and eternal life."

In these letters this title reflects the intimate, indissoluble unity between the Father and the Son (Coetzee 1993:219). They are used in the same context. One gets the impression that in his total opposition to the false prophets

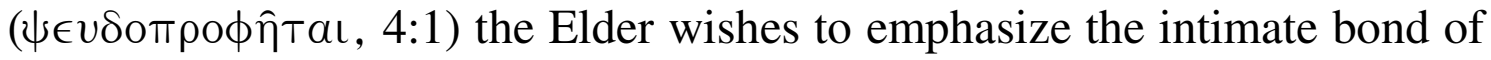
love between the Father and Son and their essential unity. Throughout 1 John Jesus is mentioned in association with the Father, predominantly with the connotation "the Father of Jesus Christ". ${ }^{27}$ 


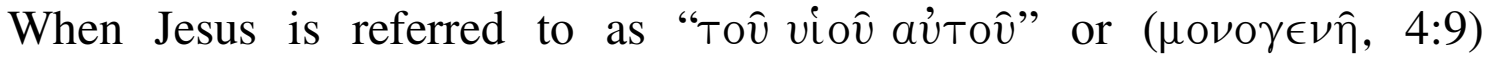

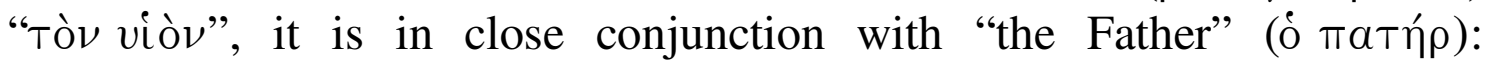

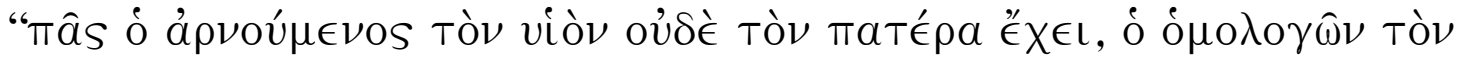

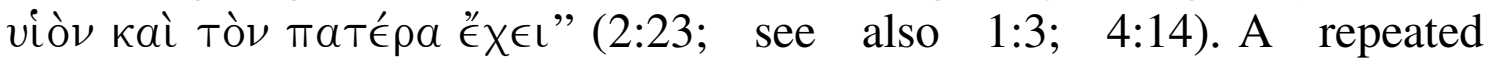
parallelism occurs, effectively putting the Father and the Son on an equal level $(1: 3 ; 2: 23 ; 4: 15 ; 5: 11,12)$ (Edwards 2000:160). The close bond between Jesus as Son and God as Father is such that for the Elder the experience of one carries with it experience of the other (2:24) (cf. 1991:72).

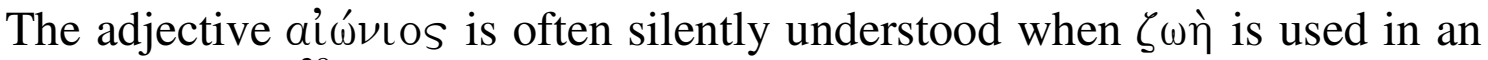
absolute sense. ${ }^{28}$ Here the gift of $\zeta \omega \eta$ has a Christological foundation. The preexistent Son of God is revealed as life (1:1-2). He has been sent into the world "so that we might live through him: (4:9). The promise of life (2:25) is founded on being in the Son, who himself is true God and eternal life (5:20). It is only through community with him that life, as a gift of God, can be received (5:11-13).

But the idea of life as a future eschatological phenomenon is also presumed by 1 John 5:13-17, when eternal life is contrasted with the sin that is mortal, which therefore does not lead to life (Strecker1996:18). ${ }^{29}$

\subsubsection{2 ảm' ảpxท̂s}

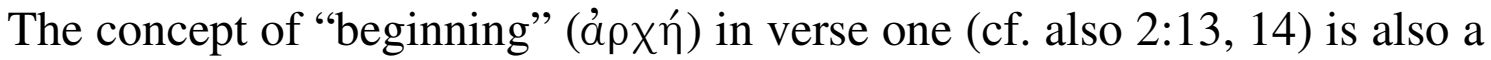
useful reference to the Son's existence with the Father before creation.

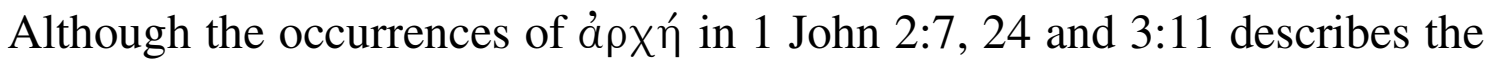
beginning of the community or (less probably) the foundation of faith through the Christ event, it cannot be denied that here in 1:1 it reveals a close relationship with the absolute understanding of the term in the prologue to the FG (1:1). If it is believed that $1 \mathrm{John}$ originated in the dependence of the FG and carries the theology of the FG farther, the Gospel's concept of ápxý would be intensified in 1 John. "The church orients itself to its origins.... Its eschatological self-consciousness is transposed into a reflection on the essence of Christian society" (Conzelmann 1974:212). This means that the theology of the Elder is articulated in the polemic against false teaching (2:23-24) and the exhortation to follow Christ and, having the FG as "a fixed authority held firmly in mind," introduces the idea of an ecclesial tradition (Conzelmann 1974:211f). ${ }^{30}$ 


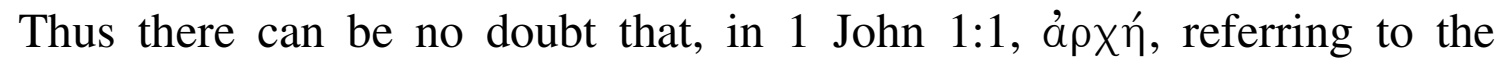
$\lambda$ óyos, describes the absolute beginning. Close parallels occur in $1 \mathrm{John}$ $1: 1 ; 2: 13-14$. At each of these points in the text the absolute is $\alpha \rho x \eta$ used in a positive Christological sense. ${ }^{31}$ Here the Elder probably follows the Johannine school's understanding of $\alpha \rho x \eta ́$, an understanding that is also presupposed by the prologue of the FG.

The absolute use of language emphasises the eschatological "pre-" of the beginning, founded on the preexistent Logos and identified with it explicitly in the FG, and implicitly in 1 John. This helps to underscore the tension between eschatology and history that is already present in 2 John 56 , a tension that shaped the beginning of the Johannine community and thus the community itself. The formulaic $\dot{\alpha} \pi{ }^{\prime} \dot{\alpha} \rho \chi \hat{\eta} s$ relieves the existing tension neither in a purely historical nor in a purely eschatological sense. Rather, it articulates the unity of eschaton and history, something that has become manifest in the Christ event and is fulfilled in the being of the church.

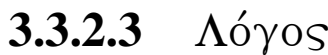

Although the Logos concept should be translated as "word," so that the genitive can be understood as objective (word of life), one still cannot exclude an epexegetical ${ }^{32}$ or qualitative ${ }^{33}$ sense. This indicates that the genitive $\tau \hat{\eta} S \zeta \omega \eta \hat{S}$ does not necessarily reduce $\lambda o ́ \gamma o s$ to an impersonal meaning (word), but rather that the Logos can also be considered here as a person; for life-giving power belongs not only to the proclaiming word but also to Christ as the preexistent and incarnate Logos (Strecker 1996:9-10). The use of this concept in the prologue of 1 John certainly reflects the usage and meaning of it in the prologue of the FG. Schnackenburg (1992:57) is of opinion that "the phrase 'concerning the word of life,' which disturbs the balance of the sentence, can be explained as due to the urgent need for qualification. As far as the content goes, both phrases

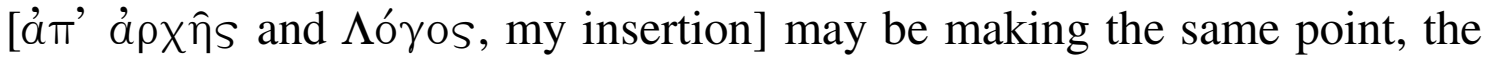
one at the beginning and the other at the end of $v$. 1 . The pre-existent Logos, and subsequently the incarnate One, incorporates in himself the fullness of the divine life, an idea that is no more clarified here than it is in GJohn."

\subsubsection{4 $\pi \alpha \rho a ́ \kappa \lambda \eta т о \nu$}

This verse (2:1) describes an activity of Jesus beyond time. The advocacy 
of Jesus Christ before the throne of God for the faithful when they fall into sin on earth is described by the use of the title Paraclete (Schnackenburg 1992:85). For the Elder the risen Lord exists with the Father. His role before the throne of God, metaphorically speaking, is consistent with what Jesus did for his disciples when he was still with them on earth. At that time he had been their protector from the evil one (17:15). Now, when they sin, he stands before God and intercedes for sinners (see also Rom 8:34; Heb 7:25; cf. 4:14-15; 9:24) (86).

\subsubsection{5 $\phi \alpha \nu \epsilon \rho \omega \theta \hat{n}$}

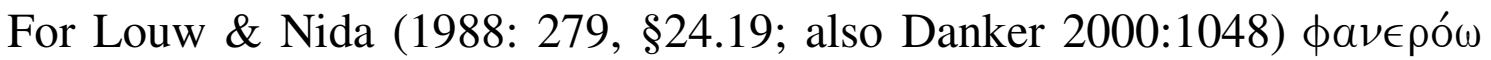
carries the meaning of: to cause to become visible- "to make appear, to make visible, to cause to be seen." The Elder uses the noun $\phi a \nu \in \rho \circ v v$ as a terminus technicus for the revelation of Christ in the past $(1: 2 ; 3: 5,8 ; 4: 9)$ and the Elder's expectation of the future (3:2) (Strecker 1996:79). This verb carries the meaning that something hidden, which implies that it already exists, is revealed. If it refers to the revelation of Christ in the past, then it infers that he already existed before he was revealed. If it refers to his revelation in future then it infers that he must exist now beyond time.

In conclusion: from the above discussion it became evident that for the Elder the Son existed with the Father from the "beginning" (before time). $\mathrm{He}$ is the Logos who is eternal life and bestows eternal life. Because he exists beyond time, according to the Elder, he is characterised as the focal point of each time sector. Therefore, he is the hermeneutical key to the construal and understanding of eschatological time in 1 John.

The following is a closer discussion of "the past and the future of time in the present".

\subsubsection{The eschatological scenario in 1 John - personification of time (objectification)}

Almost all the informal time references in 1 John are eschatological references. This makes sense because they are directly or indirectly linked with Jesus Christ. In the rest of this section it will be pointed out how Jesus, according to the Elder, is the centripetal point in each time sector of the eschatological era. Therefore, it will be argued that eschatological "time" in 1 John has been objectified/personified in Jesus Christ, because the 
eschatological past and the eschatological future are fused with the eschatological present in Christ.

\subsubsection{Future eschatological indications}

In this subsection the future eschatological indications point out the centrality of Jesus in these texts and how the future eschatological qualities (life, light, love, righteousness) ${ }^{34}$ are to be experienced in the present. In 1 John there are three major future eschatological references: 2:28; $3: 2$ and 4:17-19. These texts will be investigated now.

\subsection{The parousia in the centre - Jesus central}

The future and the present are connected through three references to Jesus' parousia and judgment $(2: 28 ; 3: 2 ; 4: 17)$. The "present eschatological" time will come to an end with the future eschatological event of the parousia and day of judgment, and will introduce a new "future or final eschatological" time (cf. Dunn 2003:295). This understanding is reflected in the close relationship that exists between verses $2: 28 ; 3: 2 \mathrm{f}$ and $4: 17$, which help us to understand what the Elder is trying to communicate concerning this eschatological event. These three verses are related, as indicated by cognate expressions and the following comparison. Only the applicable phrases were selected for this comparative analysis.

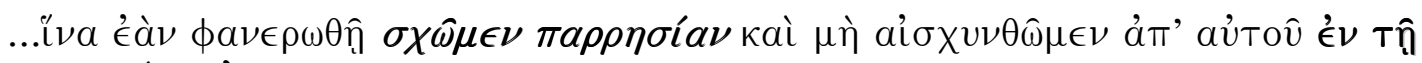
тароvбía av่Tôิ (2:28)

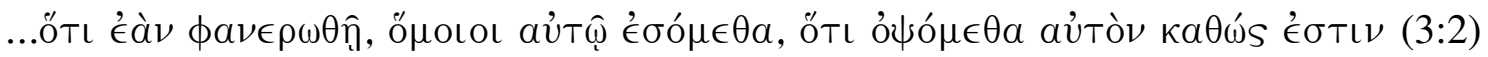

....̌va

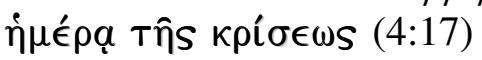

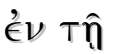

According to this analysis, it is apparent that verses 2:28 and 4:17 form a

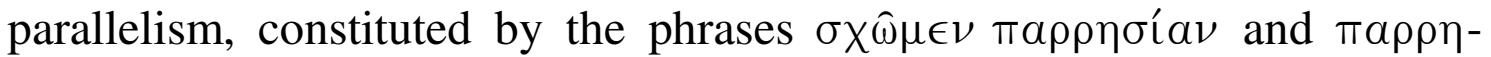
$\sigma i \alpha \nu$ '́ $\chi \omega \mu \in \nu$, and the two references concerning Jesus' future appearance,

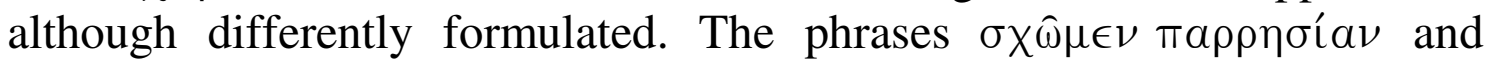

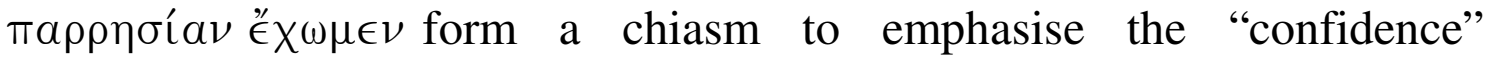
believers can have at the parousia. The parallelism also helps to relate the

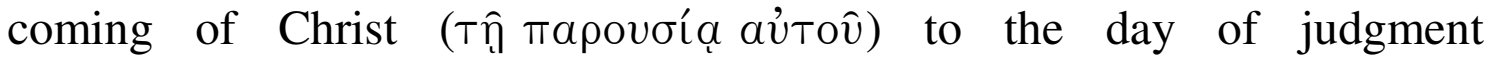
( can be deduced: the event described by the Elder as Jesus' 'revelation' $(\phi \alpha \nu \in \rho \omega \theta \hat{\eta}, 2: 28 ; 3: 2)$, is used as a compound word to depict this 


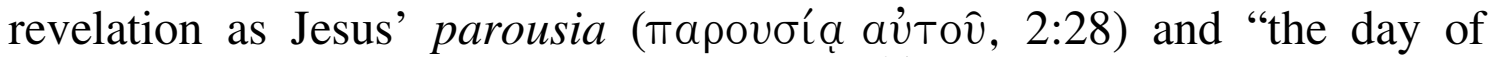

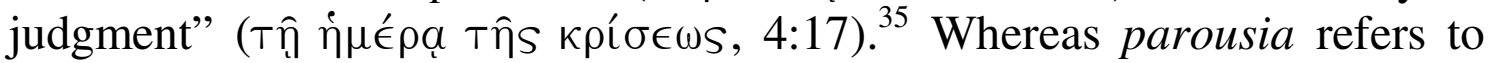
the future eschatological "event" as such, the day of judgment refers to the nature (purpose) of this event. ${ }^{36}$

If the last hour has brought the revelation of the Antichrist, it will soon end in the revelation of Christ (2:28b). The Elder gives his proclamation a special tone, for he has already spoken of another "revelation" of Christ, namely his incarnation $(1: 2 ; \mathrm{cf} .3: 5,8)$. These two events converge through the use of the same verb $\phi \alpha \nu \in \rho \omega \theta \hat{n}$. For the Elder, the tension-filled union of present and future eschatology is especially clear at this point; while $\phi a \nu \in \rho o v v$ is a terminus technicus for the incarnation of Jesus in the past $(1: 2 ; 3: 5,8 ; 4: 9)$, it is used to unmask the deceivers in the present $(2: 19)$, and also to describe the Elder's expectation for the future $(2: 28 ; 3: 2)$. The fact that the future revelation is in view here is confirmed by the fact that the revelation of Christ is equated with his parousia ${ }^{37}$ (Strecker 1996:79). Thus the Elder wants to depict these two events (incarnation and parousia) as a single, all-embracing manifestation or epiphany of God. In both these events God becomes visible on earth. At his first appearance the Son of God came to bring salvation $(4: 9,10,14)$ and to destroy the works of the devil (3:8). The first coming was an epiphany of God's love (4:9), of his redemptive involvement (3:5), whereas in the parousia Christ will appear as Judge ${ }^{38}$ (Schnackenburg 1992:152), as an epiphany of God's righteousness $(1: 9 ; 2: 29$; also 2:1 [Christ]).

Therefore, in the three texts about the future eschatological events, the Elder also exhorts his adherents to "prepare" themselves for the parousia and the day of judgment, so that they may have confidence and not be put to shame before him at his coming, and also to become like him, for they will see him as he is. These three exhortations are: abide in Christ

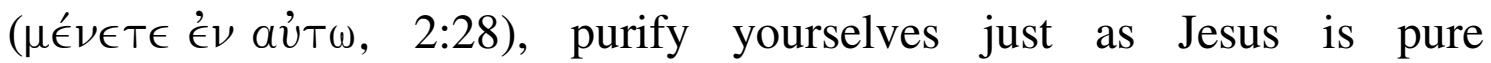

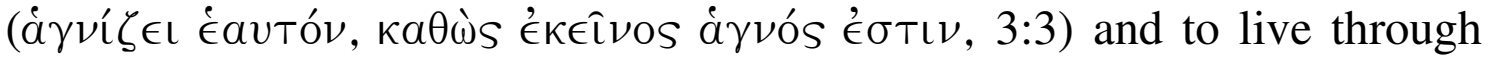

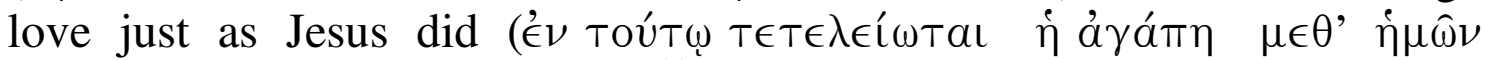

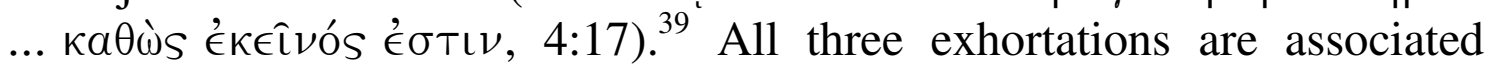
with Jesus, who is the Son of God and the personification of "divine life" (1:2). On the day of judgment, faith in him as the Son of God through whom God became incarnate, and the example of his earthly life to which

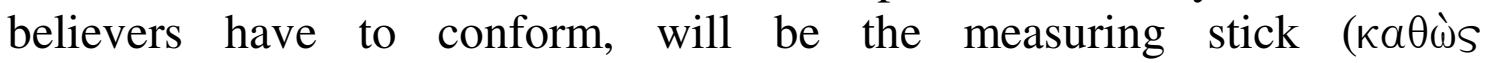

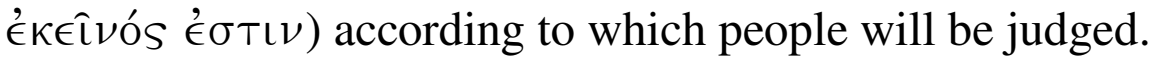




\section{Conclusion}

Jesus is central in this event. His parousia will be a day of judgment in which he will be the judge. The measuring tape will be his example on earth. Did the believer live as Jesus lived (2:6); cf also 3:3; 4:17)? The Elder uses this link to bring the future into the present or take the present to the future through Jesus. These three parousia and judgment references

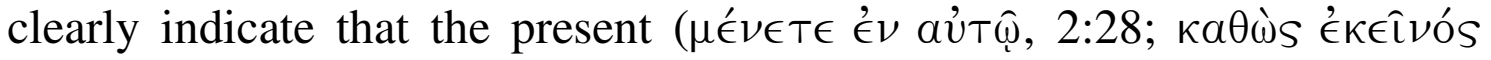

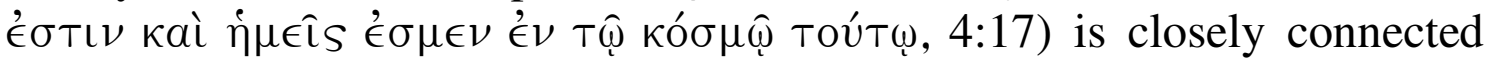

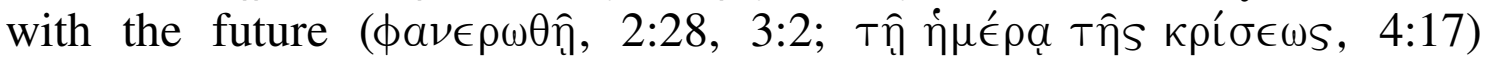

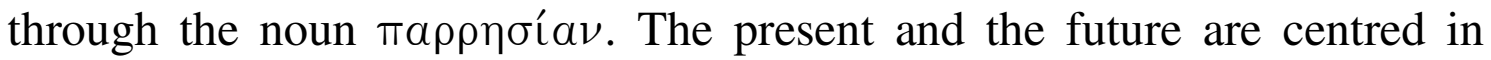
Christ. This time-centredness in Christ will now be discussed in the following section.

\subsubsection{Past eschatological indications (sent by God - 4:9, 10, 14; also revealed $-1: 2 ; 3: 8,13 ; 5: 6,20$ )}

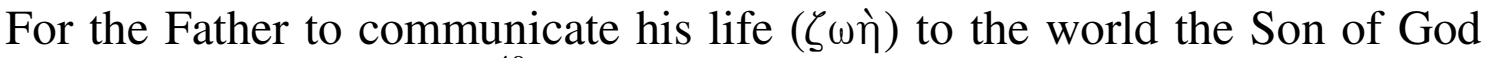
had to become incarnate. ${ }^{40}$ The incarnation was the outcome of the sending of God's only Son into the world so that God's children might live through him.

A comparison of verses 4:9, 10 and 14 indicates that they are semantically similar in their purport: $(a)$ The activity of God described in these contexts, by which his love is manifested, is regarded as salvific in purpose: the Son

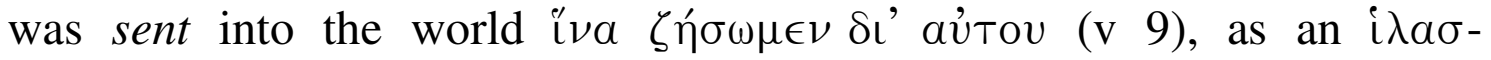

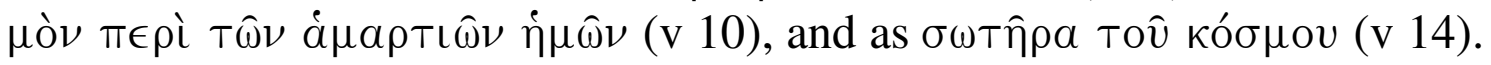
(b) In each verse it appears that God the Father of Jesus Christ is deeply involved in his world and has acted in history for the purpose of man's salvation (Dodd 1946,110f). (c) The saving act of sending Jesus involved the serving life, as well as the death, of God's Son. This is implied in 4:9 $(\zeta \eta \sigma \omega \mu \epsilon \nu)$ by the parallels in 4:10 (Jesus as i $\lambda \alpha \sigma \mu o ̀ \nu)$ and 4:14 (Jesus as $\sigma \omega \tau \hat{\eta} \rho \alpha)$. (d) Jesus is described in all three verses as Tòv viòv (v 9,

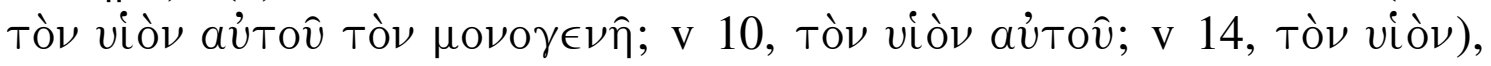
who was sent by God.

The life that God has given to his children is in his Son. In 1 John 1:1f eternal life ( in the person of Jesus Christ (cf. Du Plessis 1978:20). In 5:11f Jesus is

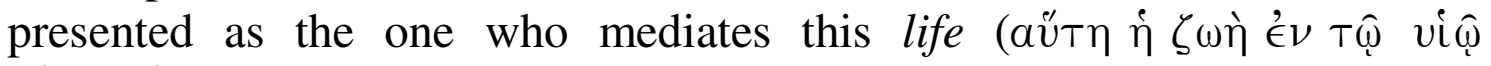

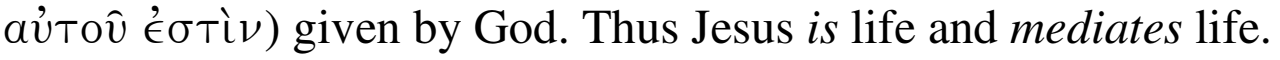


This life originally existed with the Father (1:2); and it is perfectly manifested in God's Son (cf. 5:11b). The term life is a soteriological term,

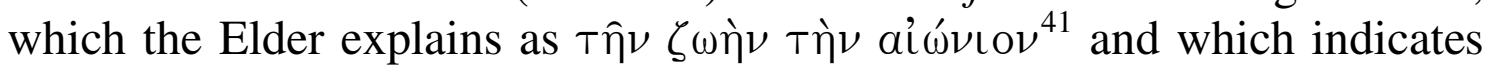
the quality of life (cf. Derickson 1993:97; Hiebert 1988:206) in God's family, which God has made available through the earthly ministry of Jesus (5:6; cf. 1:1-2; cf. John 3:16; 17:2-3). This life is characterised by the very nature of God (Hiebert 1988:206) and is a sharing of this life with God. ${ }^{42}$ Coetzee (1972:55) describes it as the "permanent oneness and life with God in Christ".

\section{Conclusion}

In these past time references the Son of God is also the focal point. His salvific deed had present and future implications. The past moved into the present and the future.

\subsubsection{The present-eschatological scenario of believers - the past and the future of time in the present}

In this subsection it will become evident how the past moved forward and the future backwards into the present and how the present way of living has future implications. This all happens, according to the Elder, through Jesus Christ.

\subsubsection{The eschaton already now $(2: 18)$}

The adjective '́์ $\sigma \chi \alpha ́ T \eta$ that has been used twice in 2:18 refers, according to Danker (2000:397), "to being the final item in a series, least, last in time."

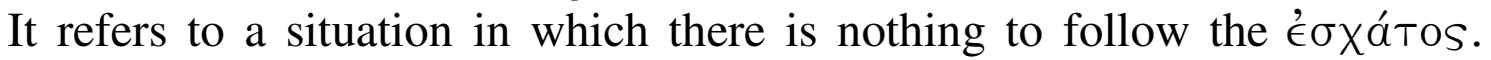
Thus, the Elder uses this adjective to bring the future into the present in its combined usage with the noun $\dddot{\omega} \rho \alpha^{43}$. In order to warn the community, to correct the false teaching about Jesus Christ and to encourage his adherents, the Elder reinterpreted this Sitz im leben eschatologically. He makes two references to the arrival of these deceivers: as "it is the last

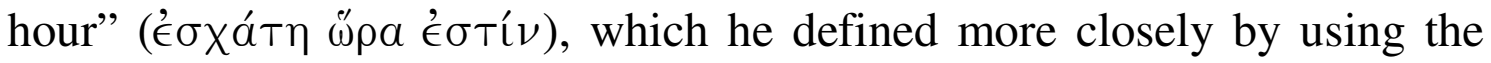
temporal particle "now" ( $\nu v \hat{\nu})$. This phrase designates, according to him, the final and decisive period in the history of humankind. ${ }^{44}$ The "last hour" is present, it is now, because the antichrists are present in the world (1 John

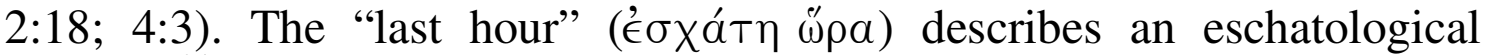
moment. ${ }^{45}$ It states that it is the last period in salvation history (Schnackenburg 1992:132; see Strecker [1996:62] for an opposite view). Therefore, it 
comes as no surprise that this section ends with a reference to the future

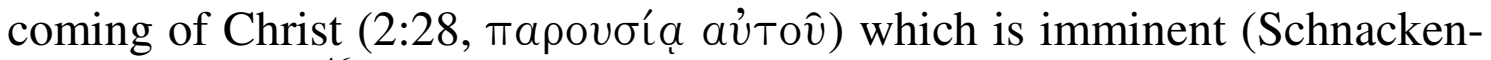
burg 1992:133). ${ }^{46}$

Because it is eschatological time for the Elder, Christ is still present in the community. His presence, according to him, is experienced through the corporative koinonia among the early Christians and their koinonia with the Father and the Son $(1: 2,3,6,7)$. This koinonia will be investigated now.

\subsubsection{The past and future of time in the present, a matter of koinōnia $^{47}$}

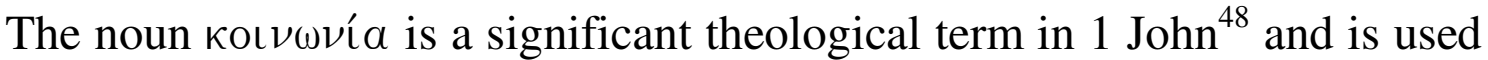
by the Elder in an eschatological sense. It occurs twice in the prooemium $(1: 3[\mathrm{bis}])$ and two more times in the rest of chapter one $(1: 6,7)$ to create a chiastic pattern. The function of the chiastic structure is to emphasize the

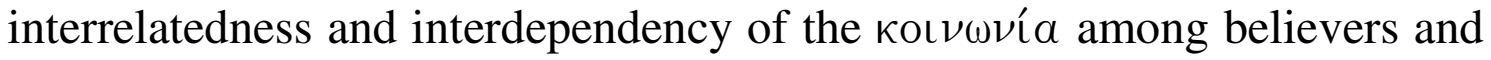

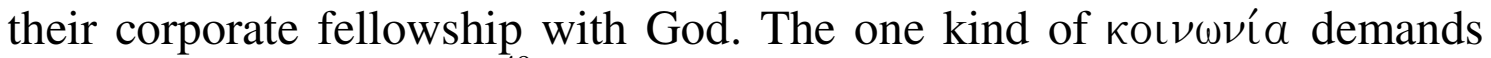
and constitutes the other" ${ }^{49}$. The Elder makes the primary reference, "we

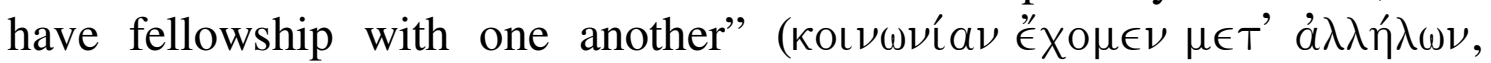
$1: 7)$, and this is dependent on "you may have fellowship with us"

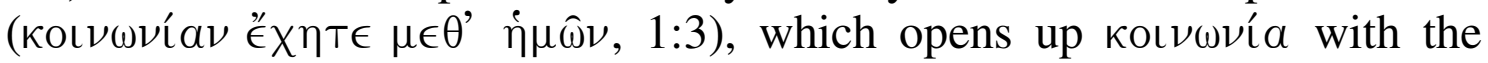
Father and his Son Jesus Christ (cf. Painter 2002:128; Rusam 1993:182;

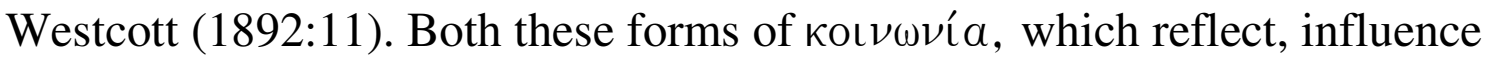
and constitute each other, occur throughout the epistle in other formulas and related deeds and imaging:

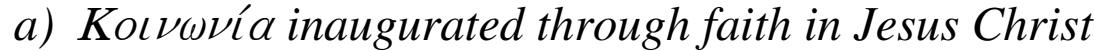

The first reference to the belief that Jesus is the Christ appears in 5:1. In the rest of ch 5 it appears twice more $(5: 5,10)$. Past and future events and qualities are experienced in the present through a relationship with Jesus Christ who was responsible in the constitution of these events and qualities in the past.

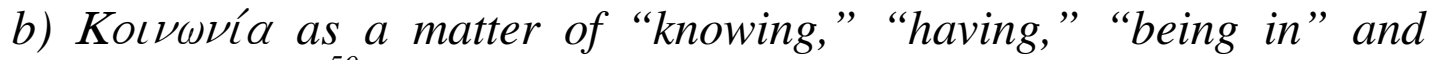
"abiding in" 50

These formulas of immanence (Immanenzformeln, Schnackenburg 1992:63-69; cf. also Lieu 1991:31-48; Strecker 1996:44) express the character of $\kappa o \iota \nu \omega \nu$ i $a$ from various perspectives that explain the qualitative lifestyle of the children of God in the familia Dei. All these closely related formulas of immanence show the central significance of this concept 


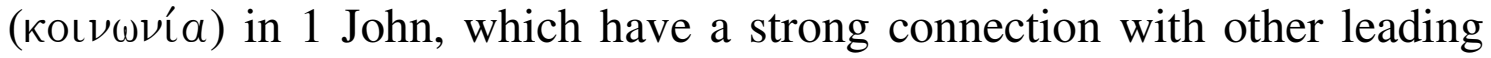
concepts, especially that of "children of God" (3:1-3), which has strong ethical implications (cf. Lieu 1991:42).

In the sphere of family life parents educate the children according to their own standards and beliefs. Therefore, "knowing the Father" will lead the children of God to correct conduct (according to his character [cf. 1:5; $2: 29 ; 4: 8,16]$ and will [2:17]). Such knowledge of God comes through the Son of God, who gives believers understanding (5:20). "Knowing Jesus" (2:3-5) is related to knowing and keeping his commands and his Word. Hence, knowledge of the Father and his Son constitutes the basis on which the individual family member and the family as an entity should live. To know God and his Son is also to know the Spirit of God (4:2) who is the Spirit of truth (5:6; cf. also 4:6). Knowing the truth implies knowing what kind of conduct is expected in the familia Dei.

The phrase "being ( $\epsilon \hat{\imath} \nu \alpha \iota)$ in God" semantically relates to "abide ( $\mu \epsilon \in v \in \iota \nu)$ in God" (they are parallel in 2:5f). The same applies in the case of "having" $\left(\epsilon^{\prime} X \in \mathrm{L}\right)$ the Father or the Son $(2: 23 ; 5: 12 ; 2 \text { John } 9)^{51}$. In 1 John, abiding is a reciprocal experience and a uniquely Johannine expression of personal fellowship. When the children of God obey his commands or live in love, they abide in God as God abides in them (3:24; 4:12-16).

By using these formulas the Elder encourages his adherents to get their

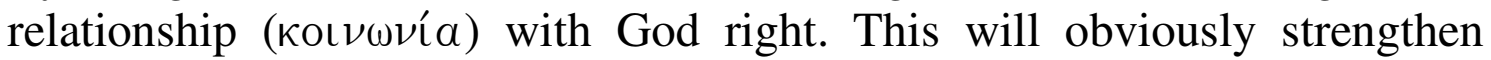
their Kolv $\omega \nu$ í $\alpha$ with the other members in the family. The child of God can only make these claims of immanence when these claims are justifiably matched by a life of obedience and love (2:5f) (cf. Lieu 1991, 41f).

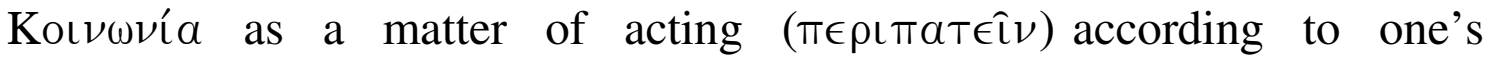
immanency. Throughout the epistles the Elder emphasises the need for the children of God to act in accordance with their status and knowledge. ${ }^{52}$ The conduct of God's children has to relate to the social conduct (rules and values) of the family into which they are born.

The Elder uses the verb $\pi \epsilon \rho \iota \pi a \tau \epsilon \hat{\imath} \nu^{53}$ (translated as "walk" or "live") as one of the etiquettes to describe such conduct in the familia Dei. In 1 John it is used five times in connection with "having fellowship" with God and one another $(1: 6,7 ; 2: 11)$ and "imitating" Christ $(2: 6)$. For "living" in the light the Elder suggests actions that correspond to God's actions (cf. Schnackenburg 1968:312). In 2:6 he states that the lifestyle of believers 


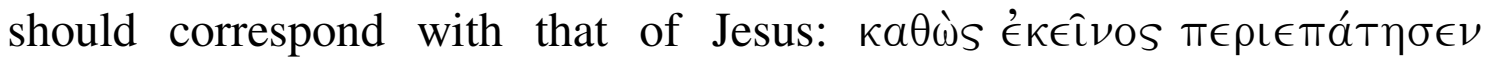

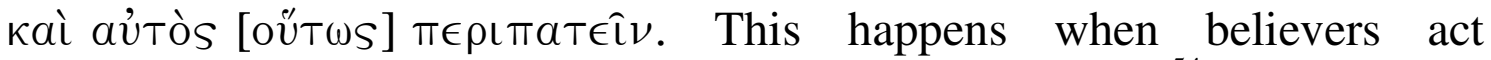
according to God's commandments $(2: 3,4 ; 2$ John 6$) .{ }^{54}$ They should

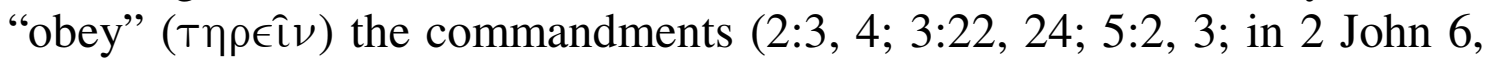

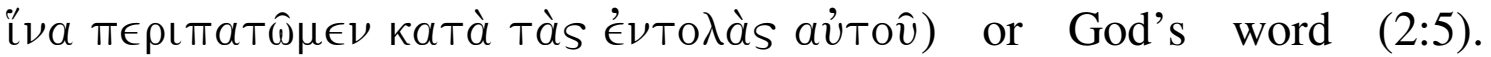

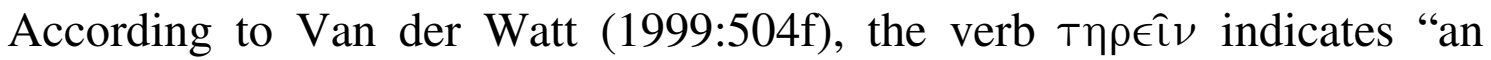
obedient orientation towards the will of God the Father" (5:1-5).

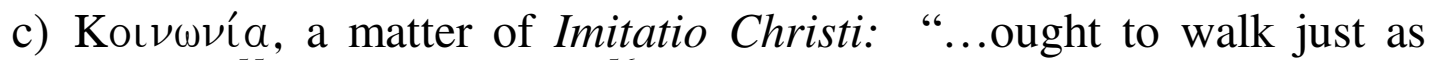
$(\kappa a \theta \dot{\omega} s)^{55}$ he walked" $(2: 6)^{56}$

This is probably what the Elder had in mind in his two "ought to" (ỏ $\phi \in i$ i $\lambda \in \mathrm{l}$, $2: 6$; 3:16) references to Christ. According to the Elder, Christ, the Son of God, is the template for the conduct of believers. Through their active participation or sharing in the way Jesus lived they have a "common" (Koเvós) ground which not only moulds the character of the children of

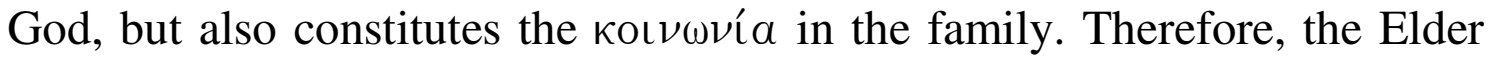
has pointed out that ethics in 1 John is not a matter of a set of rules; it is an existential way of living that is established by the attitude and behaviour of Jesus, the Son of God. This "way of living" can only actualise in believers through the Spirit. ${ }^{57}$ Through the existential guidance of Jesus and the spiritual guidance of the Spirit, the believer, as a child of God, finds his/her own way to please Him (3:22) (cf. Van der Watt 1999:505).

In his portrayal of Jesus in relation to the Father, the Elder points out the following qualities that operate in Jesus' life to which believers must conform.

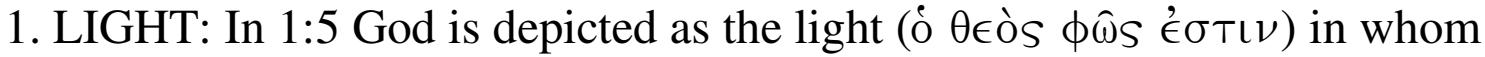
there is no darkness. In Jesus there is also no sin (3:5). Therefore, the same must be true of God's children. This implies that they must "walk in the light" as Jesus "walked in the light" and "purify themselves, just as he is pure" (3:3).

2. RIGHTEOUS: God $(1: 9 ; 2: 29)^{58}$ and Jesus $(2: 1 ; 3: 7)$ are both depicted as

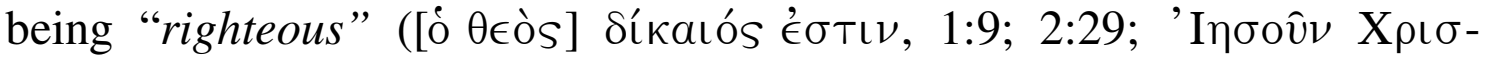

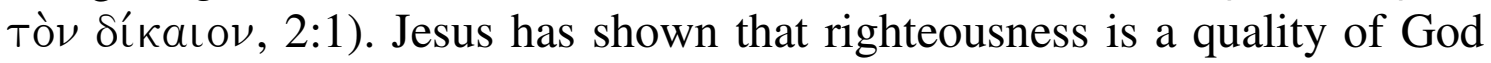
(2:1). A person is known by his/her deeds. Only through faith in Jesus (5:1), through birth from God $(2: 29 ; 5: 1)$, can a person act according to the example of Jesus. Such behaviour lies in the familial bond (Van der Watt 1999:506). 


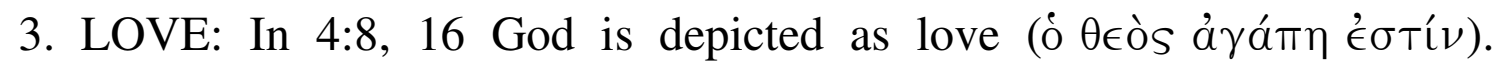
According to $3: 16$, Jesus shows what that love is by laying down his life for humankind (3:16; cf. also 4:9, 10, 14). Therefore, believers "ought to" lay down their lives for one another. In this way the love of Christ (and God; cf. 4:9-14) will be continued through believers into the lives of other believers. Jesus acts in love (3:16). Believers are exhorted to love (3:16; $4: 12$ ). Thus the familia Dei is a family of love, the sphere where God's love is communicated, shared and experienced.

4. LIFE: The children of God partake in his divine life ( God gave us eternal life, and this life is in his Son. ${ }^{12}$ Whoever has the Son has life; whoever does not have the Son of God does not have life).

It is frequently attested in the New Testament tradition that the exemplar of Jesus must lead to imitation. ${ }^{59}$ The indicative of the Jesus event "ought to" (o’ $\phi \in(\lambda \in \iota \nu)$ effect the imperative of Christian life (cf. 1 John 4:11; 5:1213). ${ }^{60}$ In comparing Christian behaviour with that of Jesus, part of the Elder's rhetoric is to motivate God's children to live in the familia Dei as Jesus did. ${ }^{61}$

\section{Conclusion}

In this subsection it also became evident that Jesus is depicted by the Elder as the object of discipleship now. He has to be the object, the person, who

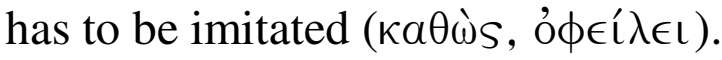

Hence, in this latter part of the article it has been pointed out that for the Elder Jesus is the centripetal and centrifugal points of the past, the present and the future in order to objectify time.

\section{CONCLUSION}

This article attempts to provide a new explanation and understanding of how the Elder interprets eschatological time in order to understand and to make sense of his circumstances. The Elder describes eschatological time not from a time perspective, but from a persons perspective. The future expectations have been revised and qualified by the assertions of the present and the past. Alongside the present the future still stands. This means that 1 John teaches both that the present fulfils the promises of God 
and that the future holds in other dimensions of the fulfilment of these promises.

Hence, the result is that 1 John presents us with what we can call a dialectical eschatology (Kysar 2007:125). This means that the qualities of this new life in Christ (eternal life) are not to be found only in the future, but in the dynamic interchange between the past, present and future. Therefore, the past and the future of time became present and the present stretches backward into the past and forward into the future. Thus, the emphasis on the eschaton is not exclusively future or exclusively present rather it embraces the "has been," the "now" and the "not yet". For the Elder there was no tension between the "has been," the "now" and the "not yet". In the writing of this epistle he objectified/personified time in Jesus Christ to create a broad "now." Thus 1 John does not disregard the past but reinterprets it in terms of the present, and also reinterprets the future in terms of the past and the present. While the past is still resuscitated in the present the "not yet" still remains a reality.

Because Jesus Christ is both the saviour and the Paraclete in 1 John, Johannine eschatological time has been objectified/personified in moving away from the mode of abstract linear time indications to a mode of specific content - Jesus Christ. For the Elder in a faith relationship with Jesus and in a life according to the life of Jesus, the past, the present and the future converge.

The areas variously called "eschatology," "apocalyptic" and the parousia of Jesus have to be rethought. We shall have to think of these time indications from a person's perspective. 
ADDENDUM A

(to be inserted here) 


\section{BIBLIOGRAPHY}

4 Esra

Available on line at: http://www.pseudepigrapha.com/apocrypha ot/ 2esdr.htm. Accessed on 30/08/2007.

Alweiss, L. 2002

Heidegger and "the concept of time." History of the Human Sciences 15 (3), 117-132.

Augustine

Augustine Confessions. Newly translated and edited by Outler A.C. 1994. Available on line at: http://www.fordham.edu/halsall/basis/confessions-bod.html. Accessed on 06/08/2007.

The Epistle of Barnabas

Available on line on: http://www.newadvent.org/fathers/0124.htm. Accessed on 19/09/2008.

Barr, J. 1969

Biblical Words for Time. London: E.C.M. Press.

Berkhouwer, G.C. 1975

The Return of Christ. Studies in Dogmatics. Grand Rapids: Eerdmans.

Bourdieu, P. 1963

The attitude of the Algerian Peasant toward Time in Mediterranean

Countrymen: Essays in the Sosial Anthropology of the Medirerranean.

Edited by Julian Pitt-Rivers. Paris: Mouton, 55-72.

Bousset, W. 1970

Kyrios Christos: a history of the belief in Christ from the beginnings

of Christianity to Irenaeus. Nashville: Abingdon Press.

Brown, R.E. 1982

The Epistles of John. Garden City: Doubleday.

Brown, R.E. 1997

An Introduction to the New Testament. London: Doubleday.

Bultmann, R 1983

Theology of the New Testament. Volume 2. London: SCM Press.

Bultmann, R. 1973

The Johannine Epistles. Transl. edited by Robert W. Funk. Philadelphia: Fortress Press.

Callahan, A.D. 2005

A Love Supreme: A History of the Johannine Tradition. Minneapolis:

Fortress Press.

Coetzee, J.C. 1972

Life (eternal life) in St. John's writings and the Qumran scrolls.

Neotestamentica 6, 48-66. 
Coetzee, J.C. 1993

The Letters of John: Introduction and Theology in The Gospel of John, Hebrews to Revelation: Introduction and Theology. Edited by Andri B. Du Toit. Halfway House: NGKerkboekhandel.

Conzelmann, H. 1974

Theologie als Schriftauslegung: Aufsätze zum Neuen Testament (BevTH 65). Munich: Kaiser.

Cullmann, O. 1967 [1951]

Christ and Time. London: SCM Press.

Culpepper, R.A. 1998

The Gospel and Letters of John. Nashville: Abingdon Press.

Danker, F.W. (ed.) 2000

Greek English Lexicon of the New Testament and other Early

Christian Literature. $3^{\text {rd }}$ rev. ed. Chicago: Uiversity of Chicago Press.

Delling, G. 1965

"kaıpós" in TDNT. Edited by Gerhard Kittel. Grand Rapids:

Eerdmans, 455-462.

Derickson G.W. 1993

What is the Message of 1 John? Bsac 150, 89-105.

De Vries S.J. 1975

Yesterday, today, and tomorrow: time and history in the Old Testament. Grand Rapids: Eerdmans.

Didache

Available on line at: http://www.newadvent.org/fathers/0714.htm. Accessed on 01/09/2007.

Dodd, C.H. 1953

The Johannine Epistles. London: Hodder and Stoughton.

Duling, D.C. 2003

The New Testament: History, Literature, and Social Context. Belmont:

Wadsworth / Thomson.

Dunn, J.D.G. 1998

The Theology of Paul the Apostle. London: T \& T Clark.

Edwards, R. B. 2000

The Johannine Epistles in The Johannine Literature. Edited by B.

Lindars, R.B. Edwards and J.M. Court. Sheffield: Sheffield Academic Press.

Eliade, M. 2005 [1954]

The Myth of the Eternal Return. New Jersey: Princeton University Press. 
Graham, R.J. 1981

The Role of perception of Time in Consumer Research. Journal of ConsumerResearch 7, 335-342.

Grayston, K. 1984

The Johannine Epistles. NCB Commentary. Grand Rapids: Eerdmans. Haas, C., De Jonge, M. \& Swellengrebel, J.L. 1972

A Translator's Handbook on the Letters of John. London: United Bible Societies.

Hawkins, S. 2008

Gave a lecture on time in Cape Town which was reported in Beeld by

E. Brits. Pretoria: News24.

Hiebert, D.E. 1988

An Exposition of 1 John 1:1-4. BSac 145, 197-210.

Johnson, T.F. 1993

1, 2, and 3 John. (NIBC). Peabody: Hendrickson. Jubilees

Available on line at: http://www.pseudepigrapha.com/jubilees/5.htm. Accessed on 01/09/2007.

Käsemann, E. 1967

New Testament Questions of Today. London: SCM Press. (225.6 KASE).

Kenney, G.C. 2000

The Relation of Christology to Ethics in the First Epistle of John. New

York: University Press of America.

Kosselek, R. 1982

Futures Past: On the Semantics of Historical Time. Trans. Keith

Tribe. Cambridge: MIT.

Kysar, R. 2007

John the Maverick Gospel. Louisville: Westminster John Knox Press. Lieu, J. 1991

The Theology of the Johannine Epistles. Cambridge: Cambridge University Press.

Louw, J.P. \& Nida, E.A. 1988

Greek-English Lexicon of the New Testament based on Semantic Domain. (2 Vol). New York: United Bible Societies.

Louw, J.P. \& Nida, E.A. 1996

Greek-English lexicon of the New Testament: Based on semantic domains (Libronix electronic ed. of the 2nd edition.) United Bible societies: New York.

Malina, B.J. 1989

"Christ and Time: Swiss or Mediterranean." CBQ 51,1-31. 
Malina, B.J. 1996

Christ and Time: Swiss or Mediterranean in The social world of Jesus and the Gospels. Edited by Bruce Malina. London: Routledge, 179214.

Malina, B.J. 1998

Social-science commentary on the Gospel of John. Minneapolis: Fortress Press.

Needham, J. 1981

Time and Knowledge in China and the West in The Voices of Time: A Comparative Survey of Man's Views of Time as expressed by the Sciences and their Humanities. Edited by $\mathrm{J} \mathrm{T}$ Fraser. Amherst: University of Massachusetts Press, 92-135.

Oxyrhynchus 655 papirus

Available on line at: http://www.gnosis.org/naghamm/thomas poxy. htm. Accessed on: 22/09/2008.

Painter, J. 2002

1, 2, and 3 John. Collegeville: The Liturgical Press.

Philo of Alexandria (trans. by Yonge, C.D.), 1996.

De fuga et inventione. The works of Philo: Complete and unabridged.

Libronix electronic version. Hendrickson: Peabody, (326).

Philo of Alexandria (trans. by Yonge, C.D.), 1996.

Legatio ad Gaium. The works of Philo: Complete and unabridged.

Libronix electronic version. Hendrickson: Peabody, (764).

Philo of Alexandria (trans. by Yonge, C.D.), 1996.

De gigantibus. The works of Philo: Complete and unabridged.

Libronix electronic version. Hendrickson: Peabody, (152).

Puech, H-C. 1957

"Gnosis and Time" in Man and Time. London. Papers from the Eranos

Yearbook 3, 38-84.

Plato

Timaeus, 37d. Translated by Bemjamin Jowett. Available on line at:

http://classics.mit.edu/Plato/timaeus.html. Accessed on 15/10/2007. Plato

Timaeus, 37e. Translated by Bemjamin Jowett. Available on line at:

http://classics.mit.edu/Plato/timaeus.html. Accessed on 15/10/2007. Plato

Timaeus, 38a. Translated by Bemjamin Jowett. Available on line at:

http://classics.mit.edu/Plato/timaeus.html. Accessed on 15/10/2007.

Psalms of Solomon

In christian apologetics \& research ministry. Available on line at: 
http://www.carm.org/lost/solomonpsalms.htm Accessed on 15/10/ 2007.

Reinhardt, K. 1940

Herodots Persergeschichte in Geistige Überdieferung. Edited by $\mathrm{E}$ Grassi. Berlin, 141ff.

Reitzenstein, R. 1966

Poimandres: studien zur griechischagyptischen und fruhchristlichen

Literatur. [S.I.]: Teubner.

Rordorf, W. 1968

Sunday: The History of the Day of Rest and Worship in the Earliest centuriesof the Christian Church. Philadelphia: Westminster.

Rusam, D. 1993

Die Gemeinschaft der Kinder Gottes. Berlin: Kohlhammer.

Schnackenburg, R. 1968

Christian existence in the New Testament. [S.1.]: Univ. of Notre Dame.

Schnackenburg, R. 1992

The Johannine Epistles. New York: Crossroad.

Smalley, S S 1984

1, 2, and 3 John. WBC. Waco. Tex.: Word Books.

Steensgaard, P. 1993

Time in Judaism in Religion and Time. Edited by A.N. Balslev \& J. Mohanty (eds). Leiden: Brill, 63-108.

Strecker, G. 1996

The Johannine Letters. Minneapolis: Fortress Press.

Thomas, J.C. 2004

A Pentecostal Commentary on 1 John, 2 John, 3 John. Cleveland: The Pilgrim Press.

Snodderly, B. \& Van der Merwe, D.G. 2007

Status degradation in first John: social scientific and literary perspectives. Acta Patristica et Byzantina 18, 179-213.

Van der Merwe, D.G. 2002

$\omega \rho \alpha$ a possible theological setting for understanding Johannine eschatology. Acta Patristica Et Byzantina 13, 253-285.

Van der Merwe, D.G. 2001

Imitatio Christi in the Fourth Gospel. Verbum et Ecclesia 22 (1), 131148.

Van der Merwe, D.G. 2006

"A matter of having fellowship": Ethics in the Johannine epistles in Identity, Ethics and Ethos in the New Testament. Edited by J.G. van der Watt. Berlin, NY: Walter de Gruyter, 535-564. 
Van der Watt, J.G. 1999

Ethics in First John: A Literary and Socio-scientific Perspective. $Q B C$ 61, 491-511.

Von Rad, G. 1977 [1975].

Old Testament Theology. Volume Two. London: SCM Press.

Westcott, B F 1892

The Epistles of st John. London: MacMillan and Co.

\section{NOTES}

1 In this article it has been accepted, in agreement with the point of view of most scholars, that the three Johannine epistles were written by the same person, referred to in 2 John 1 and 3 John 1 as the $\pi \rho \in \sigma \beta u ́ t \epsilon \rho O S$ (Brown 1997:398; Culpepper 1998:251; Duling 2003:439; Thomas 2004:4; Callahan 2005:2). Therefore, in this document, the author will be referred to as "the Elder".

2 I trust that Malina not only refers to social experiences but also religious experiences.

3 Cyclical time movement can be either absolute or spiral. Procedural time concerns the perception of the events of human experience as processual unities that have to be done right and carried to term. What counts here is the adequate completion of activities despite the amount of time spent on it. Here the present covers the entire period of the process in question. Such processes are presumed to be significant for assessing the quality and meaning of human behavior. Procedural time refers to those human experiences that happen rarely or only once to human beings; these are infrequent occurrences. It refers to the completion of some antecedent, necessary event. Thus: "when the fullness of time was come, God sent forth his Son" (Gal 4:4; Eph 1:10). Similarly, the sequence of events that have to occur of the unfolding of the scenario of the coming Son of Man (Mark 13:3-27 and parallels) points to procedural time. Graham (1981:337) notes: "Once the event begins, the stages in its completion have no time dimension to them, ..."

4 Reinhardt (1940:141ff) states that: "According to Herodotus, the law of time which events obey is not chiliastic, does not press on towards a future, cannot be compared to a stream, nor is in any sense whatsoever eschatological, but it is cyclical, periodic, always turning back to its beginning once the end has been reached. His [Herodotus's] philosophy is ... that human affairs run in a cycle ...."

5 It is noteworthy to note that Plato in $T i .37 \mathrm{~d}$ sets $\alpha i \omega \nu$, eternity, over against Хpóvos, time (cf. Philo Fug. 57; Philo Leg. Gai.. 85).

6 Heraclitus teaches that cyclically the cosmos is consumed by fire, all at once reverting back to its original state. Hippolytus says, "But he also asserts that 
this fire is endued with intelligence, and a cause of the management of the cosmos, and he denominates it craving and satiety. Now craving is, according to him, the arrangement of the world, whereas satiety its destruction. 'For,' says he, 'the fire, coming upon the earth, will judge and seize all things" "(Refut. 9.5). Fire as god is $\underline{\log o s}$; in a state of craving, fire brings forth all things, but when a state of satiety is reached all things are destroyed. The destruction of all things by fire is destined to occur cyclically. Diogenes Laertius gives this summary of Heraclitus' doctrine of cyclical conflagration: "And it [the cosmos] is alternately born from fire and again resolved into fire in fixed cycles to all eternity, and this is determined by destiny" (Lives, 9.8) (http://www.abu.nb.ca/Courses/GrPhil/Heraclitus. htm).

7 The same might be said for the Israelite speculative notion of "a world week of six epochs of 1,000 years each" (Rordorf 1968:48). However, both the Great Year and the World Week were based on the sort of abstract speculation and mathematical demonstration which present-orientated, experienced time people found as unreal as a dream; those conceptions belong to the imaginary realm of possibilities.

In his book The Myth of the Eternal Return, Mircea Eliade distinguished between linear (historical) time and sacred time.

$9 \quad$ See Steensgaard (1993:71) on the discussion of this change.

10 According to Cullmann (1967:81) it is viewed only from the future. It is viewed from the past because the Messianic time of salvation have not yet arrived for them; from the future because it will be an act from God. The term "mid-point" is perhaps ambiguous. It must not be interpreted as implying two quantitatively equal halves, but rather a "decisive inclusion".

This schematization I owe to Cullmann (1967:85) and Dunn (1998:465) with some minor changes. and Christianity is not different. In both cases we have to do with the linear concept of time. The difference between them lies in the division of the line. But cyclical processes also underscored present orientation. For example, Aristotle's theory or model of the return of political systems, a cyclical view of time, shows primary preference for the present; his model is essentially present oriented (cf. Koselleck 1982:41).

15 In this section I will make use especially of the work already done by Malina (1996:187) with necessary adaptations where this author differs from him. Malina's orientation about "first-mediterranean time perceptions" are useful but unfortunately not without a lot of fallacies. Malina has greatly been influenced by the work of Bourdieu (1963) under Algerian peasants. The statement of Malina that there is no concern for the future in the New 
Testament is a fallacy (Malina 1996:184), to name e.g. only one. See the rest of this article and my addendum A.

In the past, there lay their tradition of right and wrong. They had to steer their lives according to what they saw there. Moses was the important giver of the law, under which the Jews included the traditions (Jn 1:17; 7:22-23) and Abraham was the patriarch. If something could be taken back to Moses or Abraham, the problem was solved, for they were the forebears. Paul, however, understood it well. In Galatians 3-4 he uses Abraham as an important part of his argument. If Abraham could be saved by faith, without the law (which only came afterwards, in Moses' time) then surely the same would be possible for us (Gal 3:6-7; see Rom 4).

See also Snodderly \& Van der Merwe (2007:179-213) with regard to how the Elder dealt with his circumstances.

Eschatological time started with the incarnation of Jesus. See also Van der Merwe (2002: 253-285).

See Van der Merwe (2006:535-564) for a more thorough discussion on the circumstances in the Johannine Community when 1 John was written.

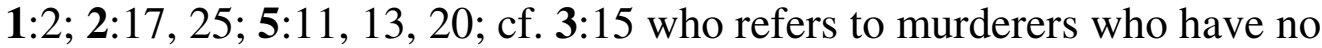
eternal life

Käsemann (1967:21) insists that John's eschatology is really a "proctology," for the goal is a restoration of all things as they were in the "beginning."

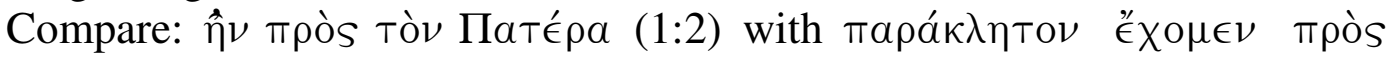
Tòv тате́ $\rho \alpha(2: 1)$

1:2, 3; 2:1, 22-24; 4:14; 2 John 3, 9; cf. also 1:2; 4:2, 3, 10; 5:10.

$1: 2 ; 3: 14 ; 5: 11-12,16$; cf. also John 1:4; 3:36; 5:24, 26, 29, 40; 6:33, 35, $48,51,53,63,68,8: 12 ; 10: 10$.

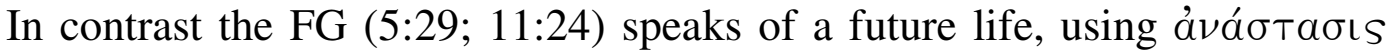
terminology.

30

This is an impressive construct, but provokes a possible counter thesis that the posited dependence must be replaced by the view that these two Johannine writings stand fundamentally theologically parallel to one another.

31 An absolute negative meaning also occurs. In the Gospel (John 8:44) it

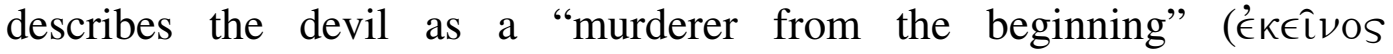

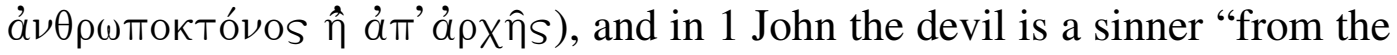

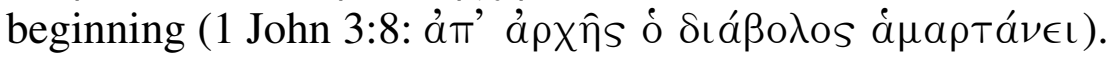


"the word that is life."

"the word that is characterized by life." See correspondingly John 6:35 (bread of life); 8:12 (light of life); Rev 21:6; 22:1, 17 (water of life).

God and Jesus are depicted in 1 John as having the following qualities: life, light, love, righteousness.

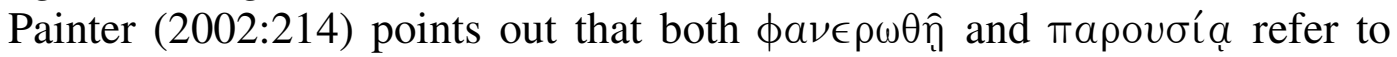
the eschatological future coming, that is implied by the earlier declaration

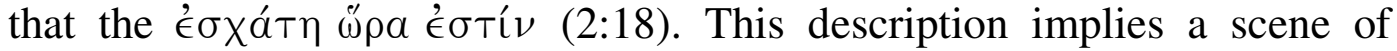
eschatological judgment.

These references to the "revelation" of Christ show how close the Elder stands, despite his own theology, to the common ideas of the early church, and how harmoniously he has fitted both together. His announcement and explanation of the last hour vibrate with genuine theology, following the general line of early Christian teaching and interpretation (cf. Schnackenburg 1992:153; Strecker 1996:79). Therefore, since no further information is given concerning this event, the rest of the NT can be consulted for more detailed information.

This thought is in harmony with the early Christian doctrine where parousia became a technical term (Matt 24:3, 27, 37, 39; 1 Thess 2:19; 3:13; 4:15; 5:23; 2 Thess $2: 1,8 ; 1$ Cor 15:23; Jas 5:7, 8; 2 Pet 1:16; 3:4). It occurs only here in the corpus Johanneum. It reflects the apocalyptic (futureeschatological) traditions presumed at the Johannine school, without giving any specific time for the coming of Christ (Strecker 1996:79). Schnackenburg (1992:152f) points out that no other term would have been so suitable in a Hellenistic environment to announce the arrival of God as king.

The prospect of "the day of judgment" (a concept taken from ancient Jewish and Synoptic eschatology) confirms that the Elder is faithful to the eschatology of the early church. See 1 Enoch 10:4ff; 16:1; 18:11ff; 22:4, 11; 4 Ezra 7:33; Jub 5:6ff; 24:28, 30; Pss Sol 15:13; etc.; Matt 10:15; 11:22, $24 ; 12: 36$. Schnackenburg (1992:223) points out that the theology of the early church adheres firmly to this (2 Pet 2:9; 3:7; Jude 6). The Day of Yahweh has often been regarded in the OT as the very heart of the prophetic eschatology (Is $2: 12 ; 13: 6,9 ; 22: 5 ; 34: 8 ; 58: 13$; Jer 46:10; Ezek 7:10; 13:5; 30:3; Joel 1:15; 2:1, 11; 3:4; 4:14; Amos 5:18-20; Ob 15; Zeph 1:7, 8, 1418; 2:2, 3; Zech 14:1; Malachi 4:5) (Von Rad 1977:119).

These three exhortations relate to the depiction of God and Christ to be Light, Righteous and Love.

To prove the reality of his incarnation the elder begins his epistle by

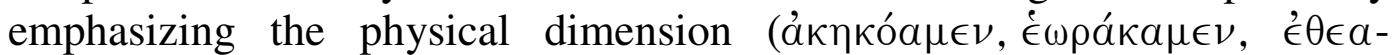
$\sigma a ́ \mu \epsilon \theta a, \epsilon ́ \psi \eta \lambda \alpha ́ \phi \eta \sigma \alpha \nu)$ of Jesus' life (1:1) (cf. Hiebert 1988:203). He

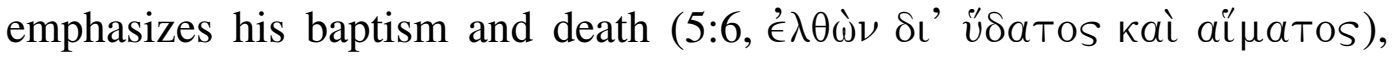




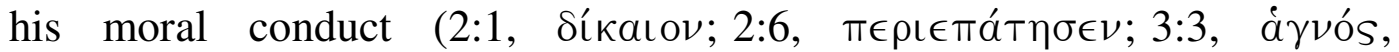

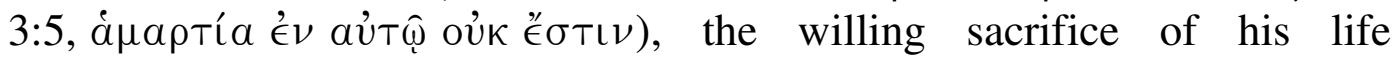

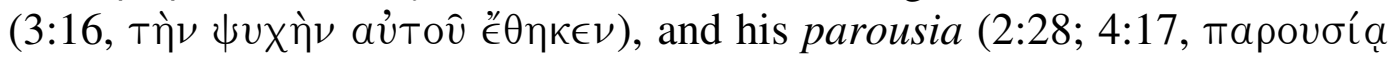
aU่Tôิ) (cf. Kenney 2000:49). Hence the Christology presented in 1 John is fully incarnational.

For this concept see John 17:2-3; also John 3:15-16; 5:24-26; 6:40, 47, 68; $10: 10,28 ; 11: 25-26$. The aorist tense of the verb " $€ \omega \omega \kappa \in \nu$ " emphasizes the factual and historical background to God's saving activity.

Cf. Smalley 1998:287; See Strecker 1996:17ff for a thorough discussion on $\zeta \omega \eta \dot{~}$

43 See Van der Merwe (2002: 253-285) for a discussion on $\omega \rho p a$ as a possible theological setting for understanding Johannine eschatology.

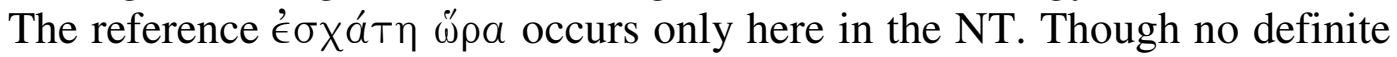
article occurs, the eschatological element is stressed by the reference to the coming of the Antichrist (Painter 2002:197; Haas 1972:62). Comparable expressions are found in the Fourth Gospel: "the hour" (5:25, 28, also without the article), and "on the last day" (6:39f, 44, 54; 11:24; 12:48; 7:37). The definite article is always used, and the reference is always to the day of resurrection which clearly differs from the last "hour", which seems to refer to a period of time immediately leading up to the last day (Painter 2002:197). Other passages such as 2 Tim 3:1 and 2 Pet 3:3 speak of

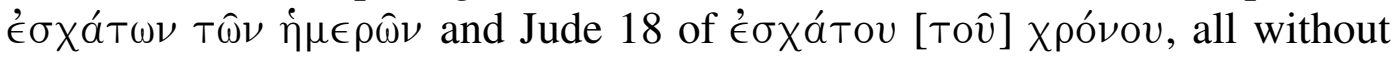

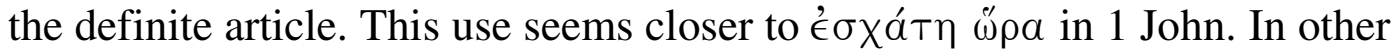
passages (cf. $3: 18 ; 4: 23 ; 5: 25$ ) the Fourth Gospel views the final decision as being an accomplished fact.

Danker (2000:1103) confirms this when he defines $\dddot{\omega} \rho \alpha$ in this context as "a point of time as an occasion for an event, time." Therefore, Schnackenburg (1992:133) rightly states that the "last hour" does not mean the entire period since the coming of Christ, or since his resurrection. Neither is it a phase or a particular period within time as it draws to its close. This reference also does not imply a precise chronological scheme for the Elder's eschatological understanding. With the warning that the "antichrists have come," the Elder only wants to say that his own time has an eschatological importance. Also see Van der Merwe (2002:253ff) for the Fourth Evangelist's use of $\omega^{\prime} \rho$, a possible theological setting for the understanding Johannine eschatology.

46 The imminence of the parousia by the Elder relates to the point of view expressed by other Christian theologians: 1 Cor 7:29ff; 16:22; Rom 13:11; Phil 4:5; 1 Thess 5:1ff; 2 Thess 2:2f; Heb 10:25, 37; Jas 5:8; 2 Pet 3:9; 1 Clem 23.2; Did 10.6; Barn 4.1ff; 21.3, 6; cf. also Mark 13:6. In these texts no specific use of the noun "antichrist" occurs (cf. Schnackenburg 1992:133fn 6). 
Within scholarship two distinct and disparate views have developed concerning the message of $1 \mathrm{John}$. They have arisen as a consequence of two variant perceptions of the purpose of the epistle. The one comprises

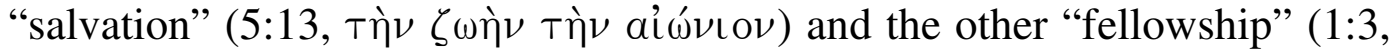

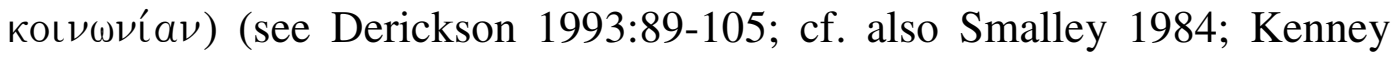
2000). In fact, they complement one another. Both these themes are mentioned in the prologue to 1 John, where the Elder gives, as we may expect, a synopsis of his principal motifs. In this chapter the emphasis falls on the "fellowship" perspective.

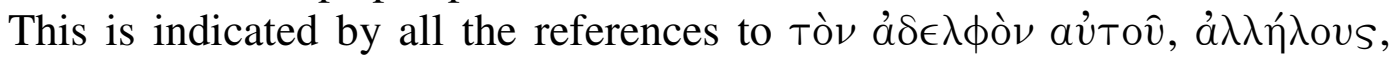
plural personal pronouns, and verbs in plural. Although the formulas of immanence refer primarily to fellowship with God, fellowship with one another is also implied.

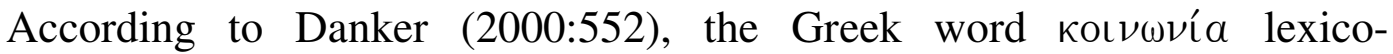
graphically means "close association involving mutual interests and sharing, association, communion, fellowship, close relationship." The semantic meaning, according to Louw and Nida (1988:446), relates to Danker's definition: "an association involving close mutual relations and involvement - 'close association, fellowship'."

Founded on the above related definitions and based on the adjective

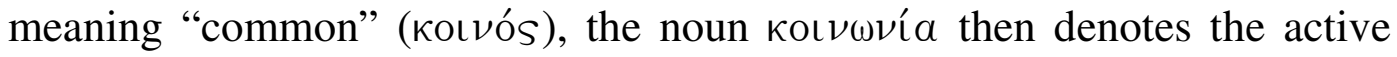
participation or sharing in what one has in common with others: doing something together or sharing something (Haas, De Jonge \& Swellengrebel 1972:27). The nature of what is mutually shared moulds the character of the group. In this context it refers to the "new life" (cf. 1:1, 2; 2:25; 5:11-13) the believers share with Christ (and God) and with one another. This "new life" in Christ creates and stimulates the desire for such fellowship and calls not for isolation, but for active participation with other believers in this "new life."

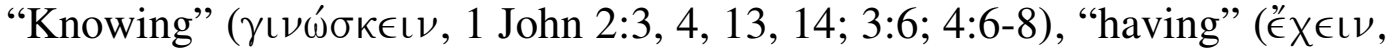

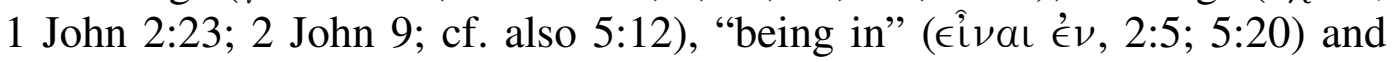
"abiding in" ( $\mu \epsilon \in \mathcal{\epsilon} \nu \nu \mathcal{\epsilon} \nu, 2: 6,24 ; 3: 24 ; 4: 13,15,16)$. Methodologically, within this purview, the formulas of immanence should also include the "abiding" in other entities which are also closely connected with God, such as: "truth" (1:8; 2:4; 2 John 2); "his word" (1:19; 2:14; cf. 2:24; 5:10); his "anointing" (2:27); "his seed" (3:9); "eternal life" (3:15); and "love" (4:12; cf. $2: 5 ; 3: 17)$; the Spirit (3:24; 4:13); God self (3:24[bis]) abiding in the believer and reciprocally the abiding of the believer in the Son $(2: 6,24,28$; 3:5, 24). Mutual abiding is referred to in 4:13, 15, 16 and 2 John 9.

51 "Having" is virtually synonymous with "believing." See the parallel between "believing in" and "having the Son" in 5:10, 12. 

10,$18 ; 4: 7$.

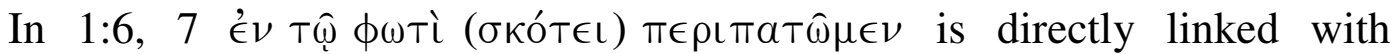

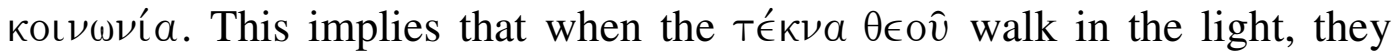
have fellowship with God and with one another. When they walk as Jesus walked, they also walk in the light.

In 2 John $\pi \epsilon \rho \iota \pi \alpha \tau \epsilon \hat{l} \nu$ occurs thrice to characterise this life in the familia

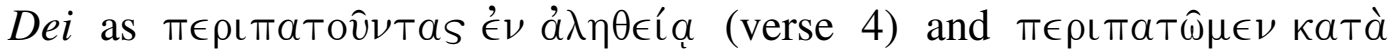

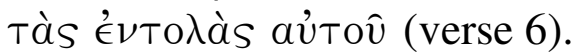

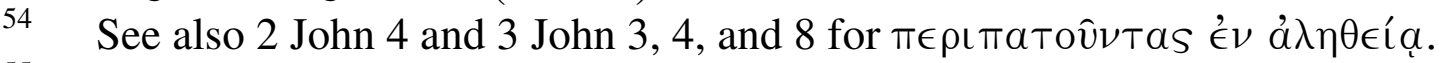

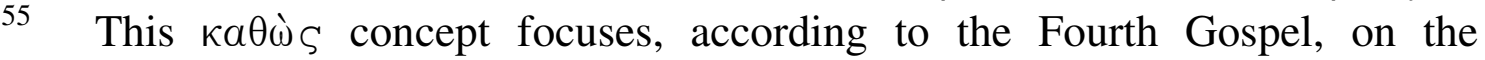
following basic aspects concerning the imitatio Christi: dependence ([5:19 $15: 5]$; $6: 57 ; 15: 15 ;[12: 49 ; 14: 10$ - 17:8]); mission $(13: 20 ; 17: 18 ; 20: 21)$; knowledge $(10: 14,15)$; love in obedience $([15: 9 ; 15: 10 ; 13: 34 f ;$ cf. 15:12]; [5:20 - 14:12]; 17:23); unity (14:10f; 14:20; [14:10 - 15:4]; 10:30; $17: 11,21-23)$; glory $(15: 8 ; 17: 1-5 ; 22-24)$; obedience of Jesus' commands (15:10) and life (6:57); also 1 Corinthians 11:1. See Van der Merwe (2001:131-148) on Imitatio Christi in the Fourth Gospel.

The obligations of the children of God in the family are spelled out in all three Johannine epistles and in each case contribute to an understanding of the behaviour of these children, which is associated with walking. 1 John 1:6 speaks of the right conduct as walking in the light, whereas 2 John 6 specifies the commandments as the sphere of walking, and 3 John 3 identifies truth as the sphere of behaviour (Kenney 2000:117). See also, кa $\theta$ ìs $(2: 6 ; 3: 3,7$; cf. also $3: 23 ; 4: 17)$ in the comparison of the believer's life with the life of Jesus.

On the role of the Spirit regarding this cf. John $14: 15-19 ; 15: 26-27 ; 16: 5-16$; 1 John 2:20, 27; 3:24.

58 Scholars are divided regarding the question whether the verb $\epsilon \sigma \tau \iota \nu$ refers to God or to Jesus. See Brown (1982:382) for a discussion on the different opinions. In this chapter Painter's point of view (2002:214f) is accepted. His arguments that "God" is implied are convincing.

Cf. 2 Cor 5:15; Phil 2:5-11; 1 Tim 6:12-13; 1 Pet 2:21-24; Heb 13:13-14. Also see Schnackenburg (1992:182). The most important ancient rhetorical

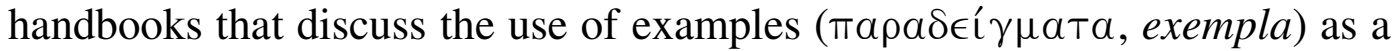
rhetorical device are Aristotle's Rhetoric, Quintilian's Institutio Oratoria, and two anonymous treatises, Rhetorica ad Alexandrum and Rhetorica ad Herennium. A lengthy discussion of what each of these rhetoricians says in regard to exempla has already been done by Cosby (1988:93ff). The question concerning the use of "examples" as rhetorical devices, was whether they had a probative or an illustrative function. 
The verb ó $\phi \in \hat{\imath} \lambda \in \mathrm{L} \nu$ with an ethical obligation also occurs in 1 John 2:6; 4:11; 3 John 8; John 13:14.

61 All this is a matter of doing the will of God the Father $(2: 17)$. Ethics in the familia Dei is determined by what the Father of the family requires. Therefore, the conduct of all the members of the family should reflect the character of the family as it is personified in the head of the family (cf. Van der Watt 1999:506). 


\section{TIME INDICATIONS IN 1 JOHN}

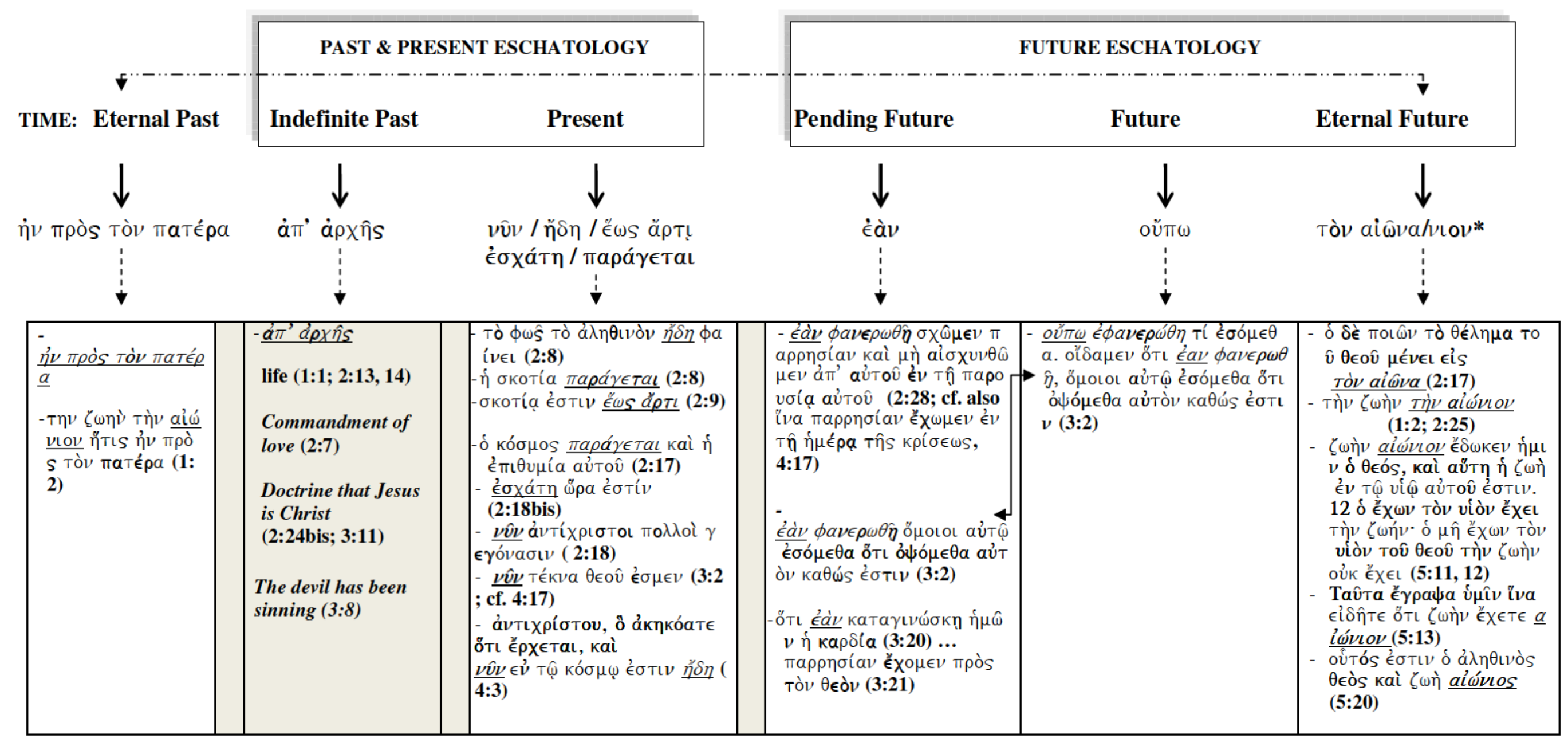

\section{Time before creation}

Time from the creation to the parousia

Time after the parousia

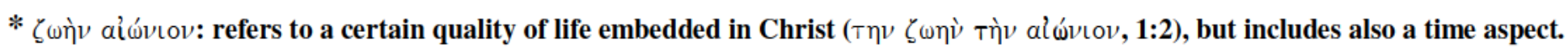

